\begin{tabular}{|l|c|c|c|c|}
\hline $\begin{array}{l}\text { Cuadernos de Investigación Geográfica } \\
\text { Geographical Research Letters }\end{array}$ & 2019 & N $^{\circ} 45(2)$ & pp. 487-513 & eISSN 1697-9540 \\
\hline
\end{tabular}

\title{
CLEARING SHRUBLAND AS A STRATEGY TO ENCOURAGE EXTENSIVE LIVESTOCK FARMING IN THE MEDITERRANEAN MOUNTAINS
}

\author{
T. LASANTA*, E. NADAL-ROMERO, J.M. GARCÍA-RUIZ \\ Instituto Pirenaico de Ecología, Consejo Superior de Investigaciones Científicas (IPE-CSIC), \\ Campus de Aula Dei, Apartado 13.034, 50080 Zaragoza, Spain.
}

\begin{abstract}
The European Mediterranean highlands have undergone a sharp economic decline from the mid-20 $0^{\text {th }}$ century, causing heavy environmental impacts and loss of ecosystem services. These mountain areas have limited opportunities to integrate into in the current financial system, which demands high productivity from workers and a very competitive product. Extensive livestock farming is one of the few activities able to survive in this context, as it needs little labour and can make use of poor grazing resources. In the north-west Iberian Range, northern Spain, the Leza valley (La Rioja) is showing a growing interest in developing extensive livestock farming. To this end, the regional Government is implementing a pasture regeneration plan for clearing shrubland. Since 1986, almost 30\% of the shrubs have been cleared, mainly abandoned fields recolonized by Genista scorpius on lime substrate, and Cistus laurifolius on siliceous substrate. This has increased the available pasture, as the average production in $\mathrm{G}$. scorpius areas has risen from $4566 \mathrm{Mj} \mathrm{ha}^{-1} \mathrm{yr}^{-1}(\delta \pm 1271)$ to $10,167.3 \mathrm{Mj} \mathrm{ha}^{-1} \mathrm{yr}^{-1}(\delta \pm 2850.3)$, and on C. laurifolius areas from $2435 \mathrm{Mj} \mathrm{ha}^{-1} \mathrm{yr}^{-1}(\delta \pm 492)$ to $7628.6 \mathrm{Mj} \mathrm{hal}^{-1} \mathrm{yr}^{-1}$ $(\delta \pm 1428.2)$. The livestock numbers show an upward trend, going from $1833.9 \mathrm{LU}$ in 1972 to $7207.8 \mathrm{LU}$ in 2017, with a simultaneous increase in the size of farms (27.6 LU in 1972 and 115.2 LU in 2017). In addition, new livestock farms established by people from outside the study area $141.7 \%$ in 2017). Finally, there is a discussion on the environmental benefits provided by extensive livestock farming.
\end{abstract}

El desbroce de matorrales como estrategia para fomentar la ganadería extensiva en la montaña mediterránea

RESUMEN. La media montaña mediterránea europea sufre un acusado proceso de marginación económica desde mediados del siglo XX con importantes impactos ambientales y pérdida de servicios ecosistémicos. Estas áreas de montaña tienen escasas posibilidades para integrarse en el sistema económico actual, que exige elevada productividad del trabajador y alta competitividad del producto. 
Entre las pocas actividades capaces de sobrevivir se incluye la ganadería extensiva, que necesita escasa mano de obra y es capaz de aprovechar recursos pastorales de escaso valor. En el valle del Leza (La Rioja, Sistema Ibérico noroccidental, norte de España) existe un creciente interés por el desarrollo de la ganadería extensiva. Para ello, el Gobierno regional desarrolla un plan de regeneración de pastizales a partir del desbroce de matorrales. Desde 1986 se ha desbrozado casi el 30\% de la superficie de matorral, fundamentalmente campos abandonados recolonizados por aliagares (Genista scorpius) en sustratos calizos y jarales (Cistus laurifolius) en sustratos siliceos. Con ello se incrementa la oferta pastoral, ya que la producción media en los aliagares pasa de $4566 \mathrm{Mj} \mathrm{ha}^{-1} a_{\tilde{n} o^{-1}}(\delta \pm 1271)$ a 10.167,3 $\mathrm{Mj} \mathrm{hal}^{-1}$ año ${ }^{-1}$ $(\delta \pm 2850,3)$ y en los jarales de $2435 \mathrm{Mj} \mathrm{ha}^{-1}$ año-1 $(\delta \pm 492)$ a $7628,6 \mathrm{Mjha}^{-1}$ año ${ }^{1}(\delta \pm 1.428,2)$. Los censos ganaderos registran una evolución alcista, pasando de 1833,9 UGM en 1972 a 7207,8 UGM en 2017, aumentando simultáneamente el tamaño de las explotaciones (27,6 UGM en 1972 y 115,2 UGM en 2017). Por otro lado, surgen nuevas explotaciones de ganaderos procedentes de fuera del área de estudio (41,7\% en 2017). Se discute sobre los beneficios ambientales que aporta la ganadería extensiva.

Key words: land abandonment, shrub clearance, pasture production, livestock farms, Iberian Range, Spain.

Palabras clave: abandono de tierras, desbroce de matorrales, producción de pastos, explotaciones ganaderas, Sistema Ibérico, España.

*Corresponding author: Teodoro Lasanta, Instituto Pirenaico de Ecología, Consejo Superior de Investigaciones Científicas (IPE-CSIC), Campus de Aula Dei, Apartado 13.034, 50080 Zaragoza, Spain. E-mail address: fm@ipe.csic.es

\section{Introduction}

Mediterranean mountain landscapes in Europe have been created through human use over thousands of years (López de Calle et al., 2001; Svenning, 2002; Blondel, 2006; Kaplan et al., 2009; Ejarque et al., 2010; García-Ruiz and Lasanta, 2018). During several centuries, the inhabitants led almost self-sufficient lives and had to make use of most of the local resources, sometimes with cattle and crops, or just by direct exploitation of the natural resources: wood, firewood, charcoal production, wild mushrooms, hunting, etc. (Blondel, 2006). However, with the industrial revolution, mechanisation of agricultural work, and globalized food and labour markets, many mountain areas have become marginalised, making it difficult to compete with urban and peri-urban areas (Puigdefábregas and Fillat, 1986; Lasanta, 2002; Navarro and Pereira, 2012). 
From the mid-20 $2{ }^{\text {th }}$ century, the Mediterranean mountains in Europe have been socio-economically marginalised. Many areas are classified as "poverty traps", where households have few resources, low returns on investment, lack of opportunities and reduced social services (Ruben and Pender, 2004; Conti and Fagarazzi, 2005; Navarro and Pereira, 2012). This situation has been reached after years of rural exodus, mainly by young people, land abandonment, decreased livestock and pasture, under-utilisation of forestry products and loss of infrastructure and services (García-Ruiz and LasantaMartínez, 1990; MacDonald et al., 2000; Sancho-Reinoso, 2013).

Socio-economic marginalisation has caused natural revegetation (Rey Benayas et al., 2007; Stoate et al., 2009; García-Ruiz and Lana-Renault, 2011; Gartzia et al., 2014; Sanjuán et al., 2018), with certain negative impacts: an increase in fire risk, degradation of cultural landscapes, reduction in bio- and eco-diversity, decreased water resources, waste of natural resources (pasture, wood, forestry by-products), loss of productive land and reduction in environmental and leisure services (Conti and Fagarazzi, 2005; Sitzia et al., 2010; García-Ruiz et al., 2011; San Román Sanz et al., 2013; Lasanta et al., 2015).

Such impacts do not only affect mountain areas and the local population, but the whole of society. It should be reminded that mountains contribute decisively to providing resources and eco-system services that are essential for the surrounding areas: water supply, high biodiversity rates, cheap wood and pastures, leisure spaces, cultural landscapes, etc. (Viviroli et al., 2003; Mottet et al., 2006). However, these goods and services are seriously compromised by depopulation and land abandonment (MEA, 2003). For this reason, scientists and land managers have shown growing interest in mountain areas in the last few decades, especially those of the Mediterranean (Gellrich et al., 2007; Stoate et al., 2009; Lasanta et al., 2015).

Since 1975, the European Union has implemented support measures for Less Favoured Areas (LFA), including mountain areas, through the Common Agricultural Policy (CAP), in order to prevent rural abandonment and maintain cultural landscapes (Dax, 2005). From then on, support measures have been taken to limit depopulation and encourage sustainable development (compensation payments for mountain areas, agricultural measures, grants to producers, improvement of the efficiency of agrarian structures, agro-forestry measures, LEADER programs, etc.), that have directed large financial resources. Just the payment of the LFA to farmers, within the Rural Development Plan (2007-2013) came to 12,600 million euros (Directorate General of Agriculture, 2011). Nevertheless, the aids seem insufficient to keep young farmers or attract new residents (Cooper et al., 2006), so the population continues aging and there is almost no one to take the place of the old farmers who retire (Keenleyside and Tucker, 2010). In the Spanish Pyrenees, for example, public policies have limited effects on rural development; just subsidies to livestock producers help to keep some farms, but many more cease due to retirement without finding a substitute (Bernués et al., 2005; Laguna Marín-Yaseli and Lasanta-Martínez, 2007).

Most of the mountains in Spain form part of the Mediterranean mountains. They have the disadvantages of mountain areas: severe winters, rugged terrain, poor 
communications and very small population centres with little capacity to promote the economy. However, they do not share some of the advantages of the high mountains (Alps, Pyrenean valleys, etc.), abundant pasture resources (hay meadows, alpine and sub-alpine pastures) and forestry, accumulated snow (water resources and winter sports), highly attractive landscapes, dynamic population centres and sufficient social services, mostly linked to tourism during recent decades (García-Ruiz and Lasanta-Martínez, 1993; Rescia et al., 2008).

Throughout the $20^{\text {th }}$ century, but especially from the $1950 \mathrm{~s}$, the Spanish Mediterranean mountain areas lost about $80 \%$ of its population and numerous villages were abandoned (Lasanta, 1990; Collantes, 2004). Social organisation fell apart and the infrastructure and services became very poor. Production reached minimum levels: most of the agricultural area was abandoned, the numbers of livestock farmers fell, and there was almost a complete loss of small artisan workshops and local industry (García-Ruiz, 1976). The very dense occupation of the area by humans for several centuries and the marginalisation from the mid- $20^{\text {th }}$ century have given rise to a much altered landscape, with very high erosion, and shrubland succession on the slopes and pine reforestation, while the natural forests occupy small areas (García-Ruiz, 1988; Douglas et al., 1994; Poyatos et al., 2003; Olarieta et al., 2008).

Between the 1950s and 1980s, neither the local inhabitants nor the public administration knew how to manage these depressed areas, which is why they can be called politically marginalised areas from a socio-economic point of view (Kuyvenhoven and Pender, 2004). Land managers only started up a reforestation plan for long-term economic (for wood and paper pulp) and environmental purposes: to regulate the runoff and reduce soil erosion on the slopes to extend the useful life of reservoirs, which led to greater depopulation and abandonment of mountain areas (Ortigosa et al., 1990), although it generated economic growth in some areas and helped to improve natural resources (Marey-Pérez and Rodríguez-Vicente, 2009). When Spain joined the EU in 1986, public policies had to be applied and large amounts of money invested in rural development and preservation of the landscape, with very poor results (Laguna Marín-Yaseli and Lasanta-Martínez, 2007; GarcíaMartínez et al., 2009).

The Iberian Range in La Rioja forms part of the Mediterranean mountain environment, showing all the signs of the developments described above. However, the regional Government of La Rioja has strongly backed extensive livestock farming as a means to keep the mountains alive, preserve the countryside and biodiversity. Especially important among the measures adopted is shrub clearing in selected areas, particularly abandoned fields, to promote the regeneration of pasture and control fire risk (Lasanta et al., 2013). Shrub clearance has been going on for over 30 years and covers a considerable area. In this context, the purpose of this paper is to find out how shrub clearing affects extensive livestock farming by analysing what is involved in the available pastures, the livestock census and the way in which livestock farms are managed. 


\section{Material and methods}

\subsection{Study area}

The Leza valley in the north-western sector of the Iberian mountain range was chosen as the study area, as it represented the characteristics of the Mediterranean mountains. It covers $274.2 \mathrm{~km}^{2}$ and includes 12 municipalities (Fig. 1), which had 645 inhabitants in $2016\left(<3\right.$ inhabit. $\left.\mathrm{km}^{-2}\right)$. Altitudes range between 600 and 1800 m.a.s.l. and during the $20^{\text {th }}$ century, many villages were depopulated, services were lost and deep changes occurred in land use and landscape dynamics: abandoned fields, and less pressure from animals on the slopes, which favour natural revegetation (Lasanta and Errea, 2001; Lasanta, 2014).

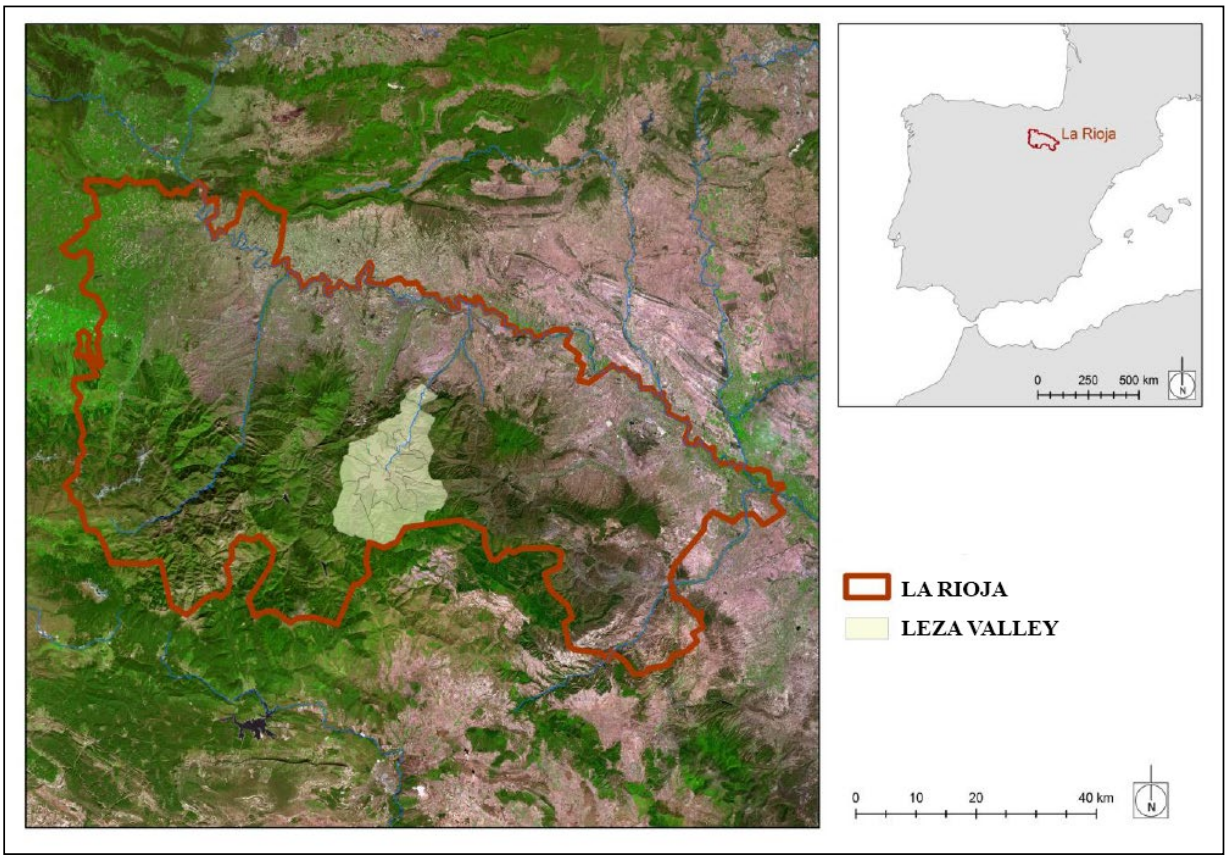

Figure 1. Study area. The Leza Valley.

The dominant lithology includes Mesozoic quartzite, sandstone and limestone. The relief features ridged summits and gentle slopes that only become steeper near riverbeds. Cuadrat and Vicente-Serrano (2008) classified the climate in the Leza valley as Mediterranean mountain. Annual rainfall ranges between 600 and $1000 \mathrm{~mm}$, depending on the altitude and exposure, with more than $60 \%$ falling in spring and autumn; the summers are dry. The average annual temperature is about $11^{\circ} \mathrm{C}$ at $600 \mathrm{~m}$ a.s.l., and $6^{\circ} \mathrm{C}$ at $1800 \mathrm{~m}$ a.s.l.

The summits of the mountains mostly comprise forests of Fagus sylvatica and Quercus pyrenaica, while Quercus rotundifolia sp. ballota grows lower down. Some slopes are covered with pines due to reforestation in the 1970s and 1980s (Ortigosa, 
1991). Shrubland containing Genista scorpius, Thymus vulgaris, Rosmarinus officinalis and Buxus sempervirens dominate the limestone soils, while Cistus laurifolius is mainly found on siliceous substrate (Arnáez et al., 2009).

The landscape transformation processes in this valley, and others parallel to it in the north-western Iberian Range, are still relatively unknown (García-Ruiz et al., 2017). In the Urbión mountains there is information on the deforestation of the montane upland and subalpine areas, with generally local fires from the middle and late Neolithic Age to enlarge summer pastures (García-Ruiz et al., 2016). These fires continued until at least the Middle Ages, because of the need for extensive pastures for transhumance activity. Pollen analysis of the peat bogs in the Sierra Cebollera shows that the forest decreased significantly from $5060 \pm 90 \mathrm{yr}$ BP, reflecting the clearing that took place in the vicinity of the peat bogs (GilGarcía et al., 1996, 2002; López de Calle and Tudanca, 2014). Similarly, a study of dolmens dating between 6000 and $3500 \mathrm{yr}$ BP at lower than 1400 m.a.s.l. shows the presence of agropastoral societies in the region from relatively early times (López de Calle and Pérez Arrondo, 1995; López de Calle and Tudanca, 2014). In the $18^{\text {th }}$ and $19^{\text {th }}$ centuries, many slopes were ploughed to grow cereals to feed the local population and replace the livestock and textile economy, which was then in crisis following the decline of transhumance at the end of the $18^{\text {th }}$ century (Gómez Urdáñez, 1986; Gómez Urdáñez and Moreno Fernández, 1997). Between the 1950 s and 1980 s, the population dropped by $72.4 \%$, the agricultural areas were abandoned and the numbers of sheep plunged, while farms arose with imported cattle breeds (Pardo-alpina, Charolaise, Hereford, Limousin, Simmental) managed by outsiders with no livestock experience (García-Ruiz and Lasanta Martínez, 1989; Lasanta and Errea, 2001). The large area of abandoned fields, a pasturing system that was not much watched over by the shepherds and the continuing replacement of sheep for cattle breed promoted shrubland succession, becoming the main feature of the landscape, to the detriment of the pastures (Errea et al., 2009). Therefore, until recent times, a large part of cattle fodder came from feed bought outside the valley (Lasanta, 2009). Therefore, the study has been carried out in a Mediterranean mountain environment under heavy use until the mid-20 ${ }^{\text {th }}$ century and marginalised since then; a region whose surface is dominated by plant succession, only interrupted by mechanical shrub clearance, and re-population (Lasanta, 2014).

\subsection{Methods}

\subsubsection{Gathering information on shrub clearance}

Information was obtained from the Agriculture, Livestock and Environment Board of the Regional Government of La Rioja on shrub clearance (regulations and area cleared annually on a municipal scale) in the Sierra Riojana, with special attention to the dossiers from the Leza valley. There is more information on this subject in Lasanta et al. (2013).

\subsubsection{Analysis of pastures and quality of grazing}

Two types of abandoned fields (with their corresponding pastures) can be distinguished in the study area, depending on soil and bedrock characteristics: (i) On basic soils (over limestone), Genista scorpius is the dominant species, a thorny plant that 
restricts grazing, although some high-quality herbaceous plants grow underneath; and (ii) on acid soils (over quartzite, microconglomerate and sandstone), Cistus laurifolius prevails, conforming extensive areas with scarce plant diversity. Henceforth, the old $G$. scorpius and C. laurifolius old fields will be named GS and CL, respectively. To analyse the availability and quality of pastures in the cleared areas, 18 cleared abandoned fields were selected, depending on the botanic composition: 9 contained mainly G. scorpius and 9 C. laurifolius, with at least 4 inventories made in each field (randomly selected $1 \mathrm{~m}^{2}$ plots). Samples were taken in spring, summer and early autumn; they could not be taken in winter as it was not possible to identify the species. These samples aimed to:

- $\quad$ Find out the composition of grazing by making phyto-sociological inventories (in the selected plots all the species were identified).

- Determine the grazing quality of the biomass by calculating the Pasture Value (PV).

Samples prior to clearing were not taken because the existence of a previous study from Marcos et al. (2004), in which the PV in GS and CL was analysed in the Iberian Range, La Rioja.

The Daget and Poissonet (1972) method, later developed by Amella and Ferrer (1979), Ascaso et al. (1996) and Barrantes et al. (2004) was used to calculate the PV.

When making the calculations, species with only a slight presence $(+)$ were not included, following guidelines from Reiné et al. (2005). The cover of each species (Specific Frequency, Fs) was estimated by transforming the phyto-sociological indices of abundance-dominance into percentages, in the following groups: $1=2.5 \%, 2=15 \%$, $3=37.5 \%, 4=62.5 \%$ and $5=87.5 \%$. Since the sum of Fs percentages is not normally $100 \%$, the specific contribution (Cs) was calculated next to bring the data up to $100 \%$ (Reiné et al., 2005). The formula below was used:

$$
\text { Cs }=\text { Fs }(100-\% \text { bare soil }) / \sum \text { Fs }
$$

Next, the pasture value was obtained using the following formula:

$$
\mathrm{PV}=0.2 * \sum(\mathrm{Cs} * \mathrm{Is})
$$

Where:

"Is" is the index of specific quality attributed to each taxon, with values ranging between 0 and 5. "Is" values were included for the natural seasons of the year and the annual average for cattle, which is the dominant species in the Leza valley. We used previous studies for this, especially the work by Ferrer et al. (1993) on abandoned fields in the Maestrazgo, southeast Iberian Range, due to the similarity in the species in the inventories and the vicinity of physical conditions in the region.

\subsubsection{Calculation of the livestock density supported by the cleared areas}

Determining the optimum livestock density of a region is quite complex as several variables intervene, such as land diversity, the type of livestock species, production objectives, and interaction between plants and animals, etc. (García-González and Marinas, 2008). In this case, to obtain the livestock density admissible in the cleared plots, 
we made some very simple calculations. The admissible density or carrying capacity is the number of animals that can graze in a region, while ensuring the sustainability of the carrying capacity of pasturelands (Freeland and Choquenot, 1990).

The livestock density was expressed in Livestock Units (LU) per unit of surface area. A LU is the equivalent of one cow for meat weighing approximately $500 \mathrm{~kg}$ (Fillat et al., 2008). To homogenize the LU count, 1 cow or 1 mare was set at $1 \mathrm{LU}$, while 1 sheep or 1 goat was equivalent to $0.1 \mathrm{LU}$. In this paper, the results are expressed as LU ha $^{-1}$ time $^{-1}$ unit (month, season, year). Normal estimates put $1 \mathrm{LU}$ for meat needing 8.2 Forage Units (FU) per day or $62.40 \mathrm{Mj}$ day $^{-1}$ (Ascaso, 1990). Some authors also express it in energy units (kcal) (Martín Bellido et al., 1986). To determine equivalence between grazing production and food needs of livestock, the following expression was used:

$$
\mathrm{FU} / \mathrm{ha} * \text { season }=15 \mathrm{PV}
$$

It must be reminded that the value of 15 was adopted taking into account the environmental conditions in the study area and in line with thoughts from Reiné et al. (2005).

\subsubsection{Information on numbers and livestock farms}

To analyse changes in livestock numbers (census and farms), information was taken from official statistics from the National Statistics Institute in the Provincial Historical Archive of La Rioja, and the District Agricultural Office (OCA) of San Román de Cameros (Regional Government of La Rioja). For farms, the data refers to their composition according to type of livestock and age of the owner.

To find out the status (continuing or ceased) of farms, the list of farms was checked for four dates (1972, 1993, 2007 and 2017) in the above mentioned organisations, and interviews were held in the municipalities in the study area. Professional farms (those with livestock as a main source of income) were differentiated from non-professional (those where livestock complements the main economic activity). As the information source did not specify this detail in the 1972 and 1993 census, it was decided that farms with less than 15 LUs (1972) and 20 LUs (1993) were not professional. For 2007 and 2017, the information was supplied by the OCA in San Román de Cameros. A farm was accepted as having continuity in the later censuses when it remained under the same owner or that of the direct heirs (sons or grandsons). Information was also obtained on the 2017 farms for the origin of the owners, in three groups: 1: owners in the study area, livestock farmers born in the Leza valley; 2: owners related to families in the study area, livestock farmers whose ancestors emigrated, but they returned; 3: owners with no previous ties to the Leza valley.

\subsection{Statistical analysis}

All data were tested for normality using the Shapiro-Wilk test and homogeneity of variances was tested using Levene's test. Analysis of variance, ANOVA, was used to compare the differences between variables (e.g. groups). A posteriori, LSD tests were used to confirm where the differences occurred between groups. All statistical analyses were carried out using SPSS Statistics 20. 


\section{Results}

\subsection{Application of the Clearance Plan by the Regional Government of La Rioja in the Leza Valley}

The Regional Government of La Rioja has been clearing shrublands since 1986, in order to promote regeneration of pastures and control fire risk. The aim is to indirectly benefit the municipalities (creating jobs, improving the landscape and preventing environmental problems) and farms (improved availability of grazing land). Interested municipalities apply for a 5-year clearance plan; the maximum surface area to be cleared in this period must be double the number of LUs, in order to direct livestock to cleared areas and control regeneration of the shrubs. Subsidies are set with a limit of 25,000 euros/municipality for a 5-year plan and financed at 420 euros/ha for the first clearance; from 2 to 5 years, a permit to remove shrub that has regrown can be applied for, and a grant of 200 euros ha- ${ }^{-1}$ and 350 euros ha- ${ }^{-1}$, respectively. The cost is borne by the Spanish Government (38.8\%), the Government of La Rioja (33.5\%), and the European Union through FEADER plans (27.7\%).

Clearance to change shrub to good grazing land for cattle comprises simple operations of mechanical clearance (Fig. 2), followed by grazing livestock in cleared areas to control regrowth. Figure 3 shows 2 images of cleared areas where traces of clearance can be observed: (i) the cleared fields are at different heights to extend the grazing period; (ii) cleared areas are combined with areas of shrub and small forests, in order to promote fodder and shelter for wild animals; (iii) steeper slopes and those near ravines have been left uncleared to reduce the risk of soil erosion; (iv) shrub is kept round the edges of the former fields as ecological corridors; (v) shrubs and trees over 1.5 to $2 \mathrm{~m}$ tall are left in the fields to promote biodiversity; and (vi) shrubs in cleared areas is for grazing different types of livestock, as cows and sheep prefer herbaceous species, while goats and mares also eat shrub.

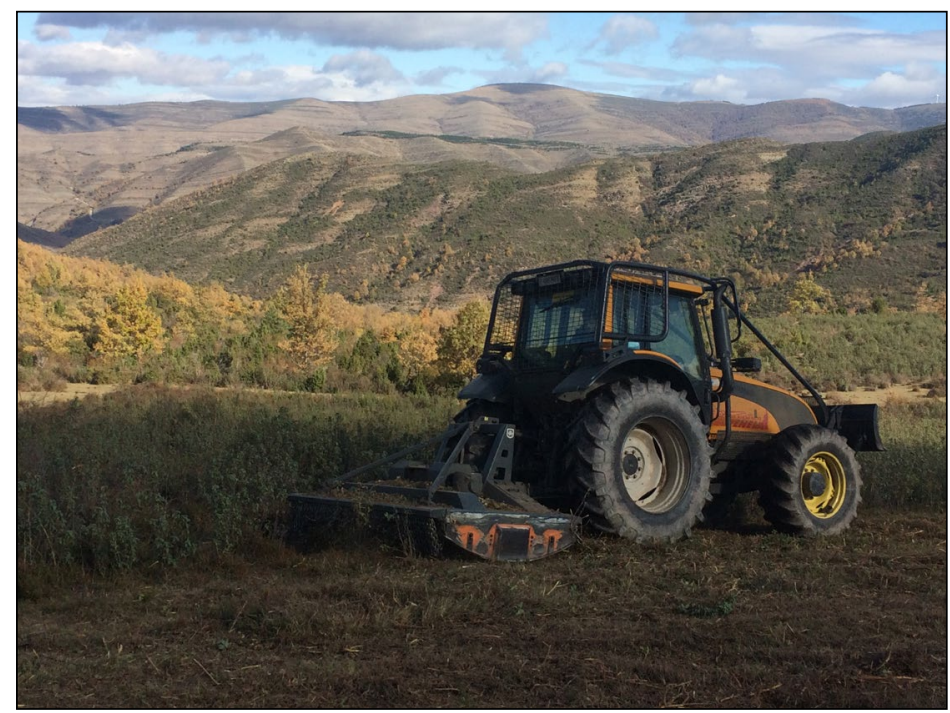

Figure 2. Tractor clearing an abandoned field covered with Cistus laurifolius. 


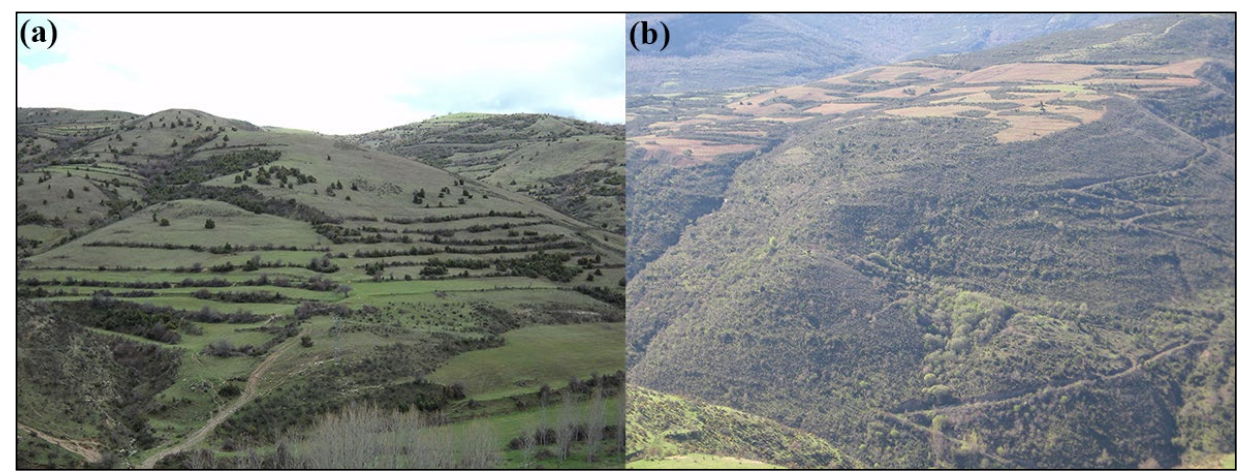

Figure 3. ( $a$ and $b$ ) Cleared areas showing the main characteristics of the old abandoned fields after the removal of the shrub cover.

Between 1986 and 2016, 32,646 ha were cleared in La Rioja, of which 30,968 ha were cleared in mountain areas, representing $23.6 \%$ of shrubland, or $12.04 \%$ of the total surface area, and 1678 ha in the foothills of the Iberian Range. In the same period in the Leza valley (Fig. 4), 5390 ha were cleared (29.5\% of the total shrublands or $18.1 \%$ of the whole valley area). Figure 4a shows the annual evolution of the cleared area, highlighting a strong interannual fluctuation, with years of more than 500 ha cleared (2002-2005) and others with no clearance, either because there were no applications/concessions or because finance was not available. In addition, from 1999 the trend line rises (Figure 4b) due to two reasons: i) the Government of La Rioja promoted the clearance plan more forcefully, having realised the benefits brought from previous years, and ii) since 2001, finance has come from the European Union via Rural Development Programs.

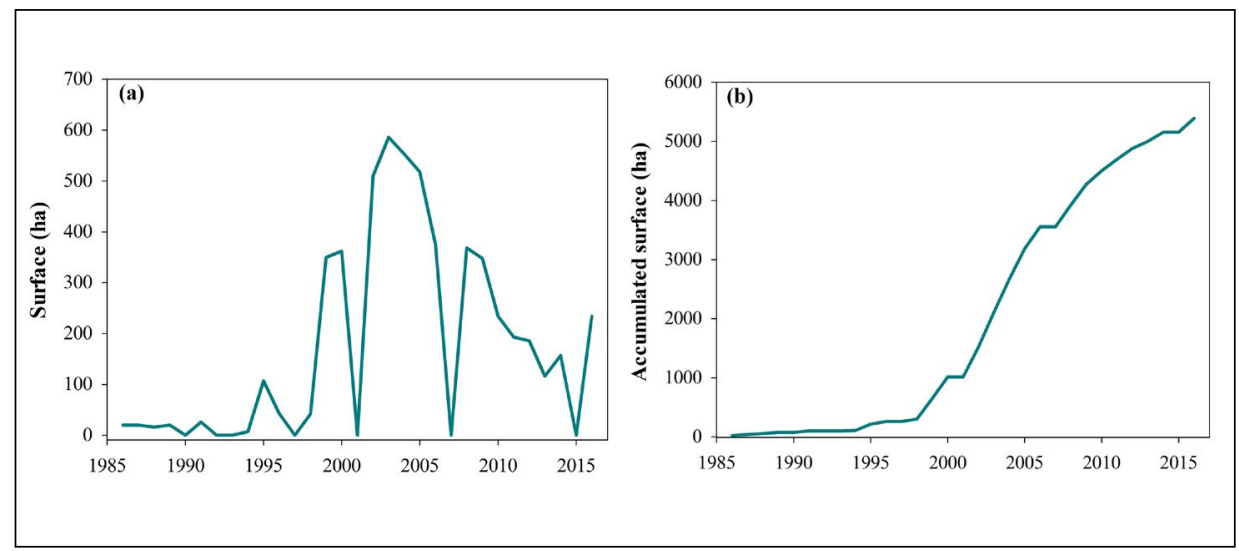

Figure 4. Evolution of the shrub clearing area in the Leza Valley (1986-2016): (a) annual evolution and (b) accumulated shrub clearing surface. 


\subsection{Grazing in cleared areas}

The phyto-sociological inventories made in cleared fields were used to find the herbaceous species and classify pastures. The fact that the study area has limestone and sandstone means that several plant communities are present, although they all intermingle so it is usually a typical community for both types of substrates. Species from nearby communities frequently appear, such that in some cleared fields a primary mix of Lolio perennis-Plantaginetum majoris and Cynosurion cristati communities, and a second mix of Lolio perennis-Plantaginetum majoris and the Sisymbrio officinaleHordeetum murini communities are recorded (Table 1). This is the consequence of the type of grazing and the effect of shrub clearance, meaning this cover arises from strong human activity. Another fact from the inventories that deserves highlighting is that there are few association characteristics. It must also be pointed out that all the inventoried communities include nitrophilous species, such as Trifolium repens, Capsella bursapastoris and Plantago major, as a result of the abundance of organic and nitrogenous material in the ground from livestock excrements. In addition, the constant trampling by livestock explains the relatively plentiful varieties of Plantago present.

Table 1. Taxonomy of the biomass inventory.

\begin{tabular}{|c|c|c|c|}
\hline Community & Class & Order & Alliance \\
\hline $\begin{array}{c}\text { Lolio perennis-Plantagine- } \\
\text { tum majoris Beger 1930 }\end{array}$ & Molinio-Arrhenatheretea & $\begin{array}{c}\text { Plantaginetalia } \\
\text { majoris }\end{array}$ & $\begin{array}{c}\text { Lolio-Plantagi- } \\
\text { nion majoris }\end{array}$ \\
\hline $\begin{array}{c}\text { Cynosurion cristati Tüxen } \\
1947\end{array}$ & Molinio-Arrhenatheretea & Arrhenatheretalia & $\begin{array}{c}\text { Cynosurion } \\
\text { cristati }\end{array}$ \\
\hline $\begin{array}{c}\text { Sisymbrio officinale-Hor- } \\
\text { deetum murini } \text { Br.-Bl. } 1967\end{array}$ & Stellarietea mediae & $\begin{array}{c}\text { Sisymbrietalia } \\
\text { officinalis }\end{array}$ & $\begin{array}{c}\text { Sisymbrion offi- } \\
\text { cinalis }\end{array}$ \\
\hline $\begin{array}{c}\text { Bromion erecti } \mathrm{W} \text {. Koch } \\
1926\end{array}$ & Festuco-Brometea erecti & Brometalia erecti & Bromion erecti \\
\hline
\end{tabular}

Source: Lasanta et al. (2013).

As stated previously, most of the clearance has been made in former crop fields that were colonised by G. scorpius and $C$. laurifolius as the dominant species. Depending on how long ago abandonment occurred, G. scorpius appears on basic soils with Juniperus communis (juniper), Rosa sp., Crataegus monogyna (hawthorn), Buxus sempervirens (box), Thymus vulgaris (thyme) and Lavandula latifolia (lavander). Herbaceous species are highly diverse, and among other species there are Helianthemum spp., Avenula spp., Brachypodium retusum, Bromus erectus, Festuca rubra. Cistus laurifolius dominates on degraded, acid soils, poor in organic matter and highly destructured; it appears together with Ononis spinosa, Lotus corniculatus, Anthyllis vulneraria, etc.

Table 2 includes the main species, grouped by families, identified in the cleared fields. It can be observed that both grasses and leguminous plants, families comprising 
species with a high forage value, are present in abundance. In an analysis based on the Bray-Curtis classification by the Jaccard index, no significant differences were found between the herbaceous strata in fields formerly dominated by Cistus laurifolius or Genista scorpius, possibly due to their proximity. The taxons appearing in the two groups of fields present very similar herbaceous communities.

Table 2. Species present in the inventories made.

\begin{tabular}{|l|l|}
\hline \multicolumn{1}{|c|}{ Family } & \multicolumn{1}{c|}{ Species } \\
\hline Grasses & $\begin{array}{l}\text { Arrhenatherum elatius, Brachypodium ramosum, Bromus erectus, Bromus hordea- } \\
\text { ceus, Bromus sterilis, Cynosurus cristatus, Dactylis glomerata, Festuca rubra, Lolium } \\
\text { multiflorum, Lolium perenne, Phleum pratense, Poa annua, Triticum aestivum, Vulpia } \\
\text { myuros, Briza media, Koeleria glauca, Poa pratensis, Hordeum murinum, }\end{array}$ \\
\hline Leguminous & $\begin{array}{l}\text { Dorycnium pentaphyllum, Genista scorpius, Lotus corniculatus, Medicago lupulina, } \\
\text { Medicago maculata, Medicago orbicularis, Medicago polymorpha, Medicago sativa, } \\
\text { Onobrychis hispanica, Ononis spinosa, Trifolium angustifolium, Trifolium campestre, } \\
\text { Trifolium ochroleucon, Trifolium pratense, Trifolium procumbens, Trifolium repens, } \\
\text { Coronilla minima, Vicia orobus }\end{array}$ \\
\hline Asteraceae & $\begin{array}{l}\text { Achillea millefolium, Bellis perennis, Hieracium pilosella, Hypochoeris radicata, } \\
\text { Santolina chamaecyparissus, Senecio jacobaea, Leucanthemum vulgare, Taraxacum } \\
\text { officinale }\end{array}$ \\
\hline Rosaceae & $\begin{array}{l}\text { Rubus ulmifolius, Agrimonia eupatoria, Geum sylvaticum, Sanguisorba minor, Cra- } \\
\text { taegus monogyna, Potentilla neumanniana }\end{array}$ \\
\hline Rubiaceae & $\begin{array}{l}\text { Asperula arvensis, Asperula cynanchina, Galium lucidum, Galium mollugo, Galium } \\
\text { saxatile, Galium verum, Sherardia arvensis. }\end{array}$ \\
\hline Lamiaceae & $\begin{array}{l}\text { Thymus vulgaris, Lamium amplexicaude, Lavandula latifolia, Prunella laciniata, Sal- } \\
\text { via verbenaca, Teucrium chamaedrys. }\end{array}$ \\
\hline Others & $\begin{array}{l}\text { Cistus laurifolius, Helianthemun canum, Convolvulus arvensis, Capsella bursa } \\
\text {-pastoris, Knautia purpurea, Scabiosa columbaria, Erica arborea, Veronica agres- } \\
\text { tis, Centaurium tenuiflorum, Malva neglecta, Malva sylvestris, Plantago lanceolata, } \\
\text { Plantago major, Plantago media, Polygala monspeliaca, Polygala nicaeensis, Ranun- } \\
\text { culus bulbosus, Daucus carota, Eryngium campestre, Aphyllantes monspeliensis, Eu- } \\
\text { phorbia serrata, Erodium cicutarium, Linum catharticum, Linum narbonense, Linum } \\
\text { suffruticosum, Muscari neglectum, Thesium humifusum, Veronica arvensis, Cerastium } \\
\text { pumilum, Cerastium glomeratum }\end{array}$ \\
\hline
\end{tabular}

Source: Lasanta et al. (2013).

\subsection{Pasture available in cleared areas}

Figure 5 compares the annual and seasonal PVs between GS and CL following clearance, taking all inventories into account. The results from the ANOVA test show that these differences are significant $(F=5.709, p=0.03)$. On an annual scale, greater growth in GS is observed, with the median value slightly over 80 and a mean value of PV $=89.1$. The values of the box plot between 70 and 100 are included. The median of CL falls to approximately 70 (mean value 66.9) and those of the box plot range between 54 and 76 . In addition, there was greater difference in the growth of GS (very elongated upper branch), 
with some plots reaching a high PV, with a top value of 147.1; while in CL the highest PV only reached 83.8. Therefore, the standard deviation in GS is \pm 25 and in CL \pm 12.5 .

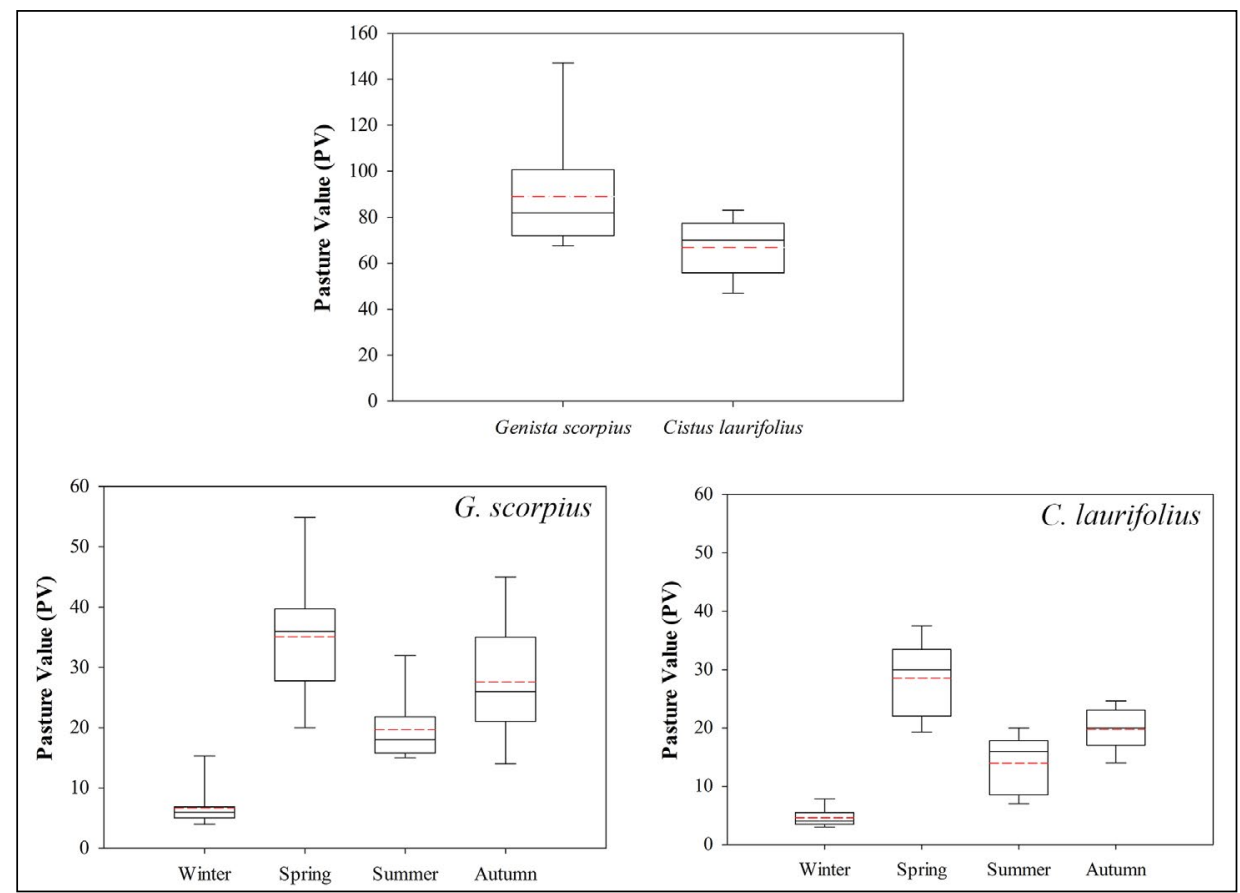

Figure 5. Annual and seasonal pasture value (PV) in cleared fields, previously covered with Genista scorpius and Cistus laurifolius. Median (solid line) and mean (dash line) values, 1 st and 3 rd quartiles, 1 st and 9 th deciles.

On a seasonal scale, the same behaviour can be seen between the former CL and GS areas, meaning greater growth in the equinoctial seasons, with a primary maximum in spring, and lower in the summer and winter, with the primary minimum in winter. The results of the ANOVA test show significant differences in all cases in both species. For all seasons, the PV is lower in CL than in GS (Fig. 5), although there are only significant differences in summer and autumn between both types of shrubs, with higher values in the latter.

Mean annual productivity in GS is $10,167.3 \mathrm{Mj} \mathrm{ha}^{-1} \mathrm{yr}^{-1}(\delta \pm 2850.3)$ and $7628.6 \mathrm{Mj} \mathrm{ha}^{-1} \mathrm{yr}^{-1}$ $(\delta \pm 1428.2)$ in CL. Figure 6 shows that most of the former GS sampled have greater productivity than CL (although the differences are not significant). In fact, the $25^{\text {th }}$ percentile of the former are slightly over $8000 \mathrm{Mj} \mathrm{ha}^{-1} \mathrm{yr}^{-1}$, while it is lower than $6.500 \mathrm{Mj} \mathrm{ha}^{-1} \mathrm{yr}^{-1}$ in the latter. Growth in GS fluctuates between 16,791.5 $\mathrm{Mj} \mathrm{ha}^{-1} \mathrm{yr}^{-1}$ and 7707.4 $\mathrm{Mj} \mathrm{ha}^{-1} \mathrm{yr}^{-1}$, while for CL it ranges between $9479 \mathrm{Mj} \mathrm{ha}^{-1} \mathrm{yr}^{-1}$ and $5335.8 \mathrm{Mj} \mathrm{ha}^{-1} \mathrm{yr}^{1}$. The most productive plots for both GS and CL also have some of the following species present: Trifolium repens, Plantago lanceolata, Poa pratensis, Medicago lupulina, Lolium perenne, Dactylis glomerata, Lotus corniculatus, Poa bulbosa and Salvia verbenaca. 


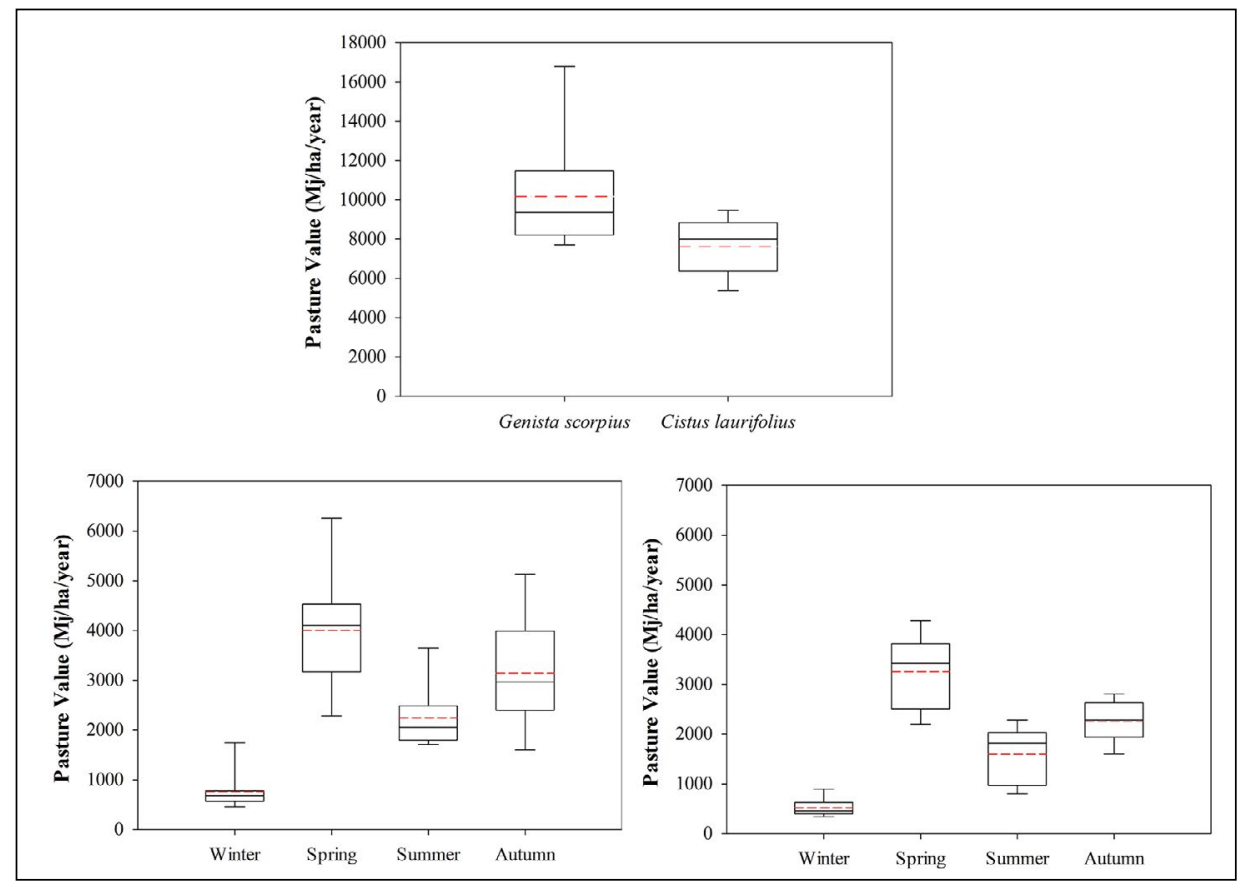

Figure 6. Annual and seasonal production $\left(\mathrm{Mj} \mathrm{ha}^{-1} \mathrm{yr}^{-1}\right)$ in shrub cleared fields of Genista scorpius and Cistus laurifolius. Median (solid line) and mean (dash line) values, 1st and $3 \mathrm{rd}$ quartiles, 1 st and 9 th deciles.

As expected, the seasonal behaviour of the annual PV values is very similar in GS and CL (no significant differences). The highest growth is reached in spring: $4005.5 \mathrm{Mj} \mathrm{ha}^{-1}(\delta \pm$ 1136.6) in GL, representing 39.4\% of the total, and $3255.6 \mathrm{Mj} \mathrm{ha}^{-1}(\delta \pm 711.6)$ in CL (52.7\% of the total). In summer, production falls to $2246.5 \mathrm{Mj} \mathrm{ha}^{-1}(\delta \pm 607.85)$ in GS (22.1\% of the annual total) and to $594.7 \mathrm{Mj} \mathrm{ha}^{-1}(\delta \pm 555.5)$ in CL (20.9\%). Rainfalls at the end of summer and the beginning of autumn enable species eaten by livestock to re-grow (Plantago lanceolata, Poa pratensis, Trifolium repens, Lolium perenne, Medicago lupulina etc.), so production rises in autumn to $3150.5 \mathrm{Mj} \mathrm{ha}^{-1}(\delta \pm 1069)$ (31\% of the annual total) and $2255.6 \mathrm{Mj} \mathrm{ha}^{-1}$ $(\delta \pm 408.1)$ (29.6\% of the annual total) in GS and CL ground, respectively. Winter halts the growth cycle in many plants, leading to a decrease in production to $764.8 \mathrm{Mj} \mathrm{ha}^{-1}(\delta \pm 382.15)$ $(7.5 \%)$ in GS, and 523.4 $\mathrm{Mj} \mathrm{ha}^{-1}(\delta \pm 175.2)(6.9 \%)$ in CL. In that season, very few species contribute to cattle fodder, the best being: Poa pratensis, Bellis perennis, Trifolium repens, Bromus erectus, Carex humilis, Lolium perenne, etc. It should also be pointed out that growth in spring contributes more to annual production in CL than in GS.

\subsection{Admissible livestock density in cleared fields}

Table 3 includes the livestock density admissible in cleared plots throughout the year and on a seasonal scale. Potential production is taken into account based on phyto- 
sociological samples and the PV calculation. Cleared GS fields can feed an average density of $0.45 \mathrm{LU} \mathrm{ha}^{-1} \mathrm{yr}^{-1}(\delta \pm 0.12)$, and CL fields at $0.33 \mathrm{LU} \mathrm{ha}^{-1} \mathrm{yr}^{-1}(\delta \pm 0.06)$. The highest food capacity occurs in spring, with a density of $0.71 \mathrm{LU} \mathrm{ha}^{-1}(\delta \pm 0.20)$ in GS and $0.06 \mathrm{LU} \mathrm{ha}^{-1}(\delta \pm 0.12)$ in CL. In the other seasons, the admissible livestock density is lower, although it helps to reduce feed consumption from feedstock. In fact, considering that in the Leza valley 5390 ha were cleared between 1986 and 2016, it can be concluded that in spring the cleared plots feed $3827 \mathrm{LU}$, if the total cleared areas were formerly GS fields, and $3224 \mathrm{LU}$ if they were CL fields, and over the whole year between 2425 and $1778 \mathrm{LU}$, respectively. If it is considered that the livestock numbers rose to $7225 \mathrm{LU}$ in 2017, it can be concluded that cleared plots can feed in spring approximately between $53 \%$ and $44.6 \%$ of the total, and throughout the year, between $33.5 \%$ and $24.6 \%$, if all cleared fields were GS or CL old fields, respectively.

Table 3. Admissible livestock density in cleared fields $(L U)$.

\begin{tabular}{|c|c|c|c|c|c|}
\hline Community & Winter & Spring & Summer & Autumn & Annual \\
\hline Gorse shrub & & & & & \\
\hline Average density & 0.14 & 0.71 & 0.40 & 0.56 & 0.45 \\
\hline Standard deviation & 0.07 & 0.20 & 0.11 & 0.19 & 0.12 \\
\hline Rock rose shrub & & & & & \\
\hline Average density & 0.09 & 0.60 & 0.28 & 0.40 & 0.33 \\
\hline Standard deviation & 0.03 & 0.12 & 0.10 & 0.07 & 0.06 \\
\hline
\end{tabular}

Source: Compilation by the authors.

Table 4 summarises what clearance means for livestock fodder. In the old GS fields, the carrying capacity increase from $0.20 \mathrm{LU} \mathrm{ha}^{-1} \mathrm{yr}^{-1}$ to $0.45 \mathrm{LU} \mathrm{ha}^{-1} \mathrm{yr}^{-1}$, while in the old CL fields it rises from $0.11 \mathrm{LU} \mathrm{ha}^{-1} \mathrm{yr}^{-1}$ to $0.33 \mathrm{LU} \mathrm{ha}^{-1} \mathrm{yr}^{-1}$; i.e. 4.99 ha of GS was needed before clearing and 9.35 ha of CL to feed $1 \mathrm{LU}$, while 2.24 ha and 2.99 ha respectively are sufficient after clearing.

Table 4. Carrying capacity of livestock before and after clearances.

\begin{tabular}{|l|l|c|c|c|}
\hline \multicolumn{2}{|l|}{ Community } & $\begin{array}{c}\text { Grazing produc- } \\
\left.\text { tion } \mathbf{~ M j ~ h a}^{-1}\right)\end{array}$ & $\begin{array}{c}\text { Admissible den- } \\
\text { sity (LU ha-1) }\end{array}$ & $\begin{array}{c}\text { Surface area } \\
\text { (ha)* }\end{array}$ \\
\hline \multirow{2}{*}{ Prior to clearing } & Genista scorpius & 4566 & 0.20 & 4.99 \\
\cline { 2 - 5 } & Cistus laurifolius & 2435.2 & 0.11 & 9.35 \\
\hline \multirow{2}{*}{ After clearing } & Genista scorpius & 10167.34 & 0.45 & 2.24 \\
\cline { 2 - 5 } & Cistus laurifolius & 7628.65 & 0.33 & 2.99 \\
\hline
\end{tabular}

*Surface area required to feed $1 \mathrm{LU}$ throughout the year.

Source: For production prior to clearance, Marcos et al. (2004), who use the same system of assessment and the same study area. For production after clearance, the information gathered in this work. Compilation by the authors. 


\subsection{Changes in livestock numbers and farms}

Table 5 includes the evolution of the livestock numbers between 1950 and 2017 . A reduction in LU is observed between 1950 and 1972, followed by an increase, with census multiplying by 3.9. Currently, and this is an extremely important information, the number of LU in the valley is significantly higher than in 1950 , or any other subsequent livestock census. During the period studied, goats suffered a sharp decline from 12,575 head in 1950 to 413 in 2007, but recovered slightly over the last decade (1040 head in 2007). Sheep, the basis for traditional livestock farming, suffered a drastic fall in census between 1950 (17,379 sheep) and 1993 (2826 sheep), with some recovery in recent decades. Horses follow the same trend as sheep, although their number in 2017 (1035 mares) was almost the same as in 1950 (1219 head), with an important difference: in 1950 they were for work on farms, and in 2017 for meat production. The most important change has been with cows, which have increased steadily from the 1970s, and multiplied census by 5.5 between 1972 (983 cows) and 2017 (5412 cows).

Table 5. Evolution of the livestock census in the Leza valley (1950-1972).

\begin{tabular}{|l|r|r|r|r|r|}
\hline \multicolumn{1}{|c|}{ Year } & \multicolumn{1}{c|}{ Cows } & \multicolumn{1}{c|}{ Sheep } & \multicolumn{1}{c|}{ Goats } & \multicolumn{1}{c|}{ Horses } & \multicolumn{1}{c|}{ LU } \\
\hline 1950 & 555 & 17,379 & 12,575 & 1219 & 4779.4 \\
\hline 1961 & 1147 & 14,699 & 5683 & 880 & 4065.2 \\
\hline 1972 & 983 & 5616 & 2893 & - & 1833.9 \\
\hline 1993 & 3645 & 2826 & 2426 & 407 & 4577.2 \\
\hline 2007 & 4570 & 4518 & 413 & 1078 & 6141.1 \\
\hline 2017 & 5412 & 6568 & 1040 & 1035 & 7207.8 \\
\hline
\end{tabular}

Source: 1950 and 1961: Agricultural Statistical Review of the Provincial Head of Livestock Development; 1972 and 1993: Chamber of Agriculture, data taken from the Provincial Historical Archive, 2007 and 2017: District Agricultural Office of San Román (Regional Government of La Rioja). Compilation by the authors.

Table 6 shows that the number of farms (both the total farms and the professional ones) decreased in the study period. Livestock farms decreased from 186 in 1972 to 77 in 2017 , a decrease around $58.6 \%$. The professional farms, i.e. those whose only activity is stockbreeding, fell by $52.8 \%$, from 125 in 1972 to 59 in 2017. In parallel, the proportion of professional farms with respect to the total has increased over the last decade from $57.8 \%$ in 2007 to $76.6 \%$ in 2017 . The average size of professional farms increased sharply between 1972 (27.6 LU) and 2007 (121.7 LU), but showed a slightly decrease in the last decade. 
Table 6. Evolution of livestock farms (1972-2017).

\begin{tabular}{|l|c|c|c|c|}
\hline Year & Totals & Professional & $\begin{array}{c}\text { \% professional/ } \\
\text { totals }\end{array}$ & $\begin{array}{c}\text { Average size of profes- } \\
\text { sional farms (LU) }\end{array}$ \\
\hline 1972 & 186 & 125 & 67.2 & 27.6 \\
\hline 1993 & 126 & 87 & 69 & 46.8 \\
\hline 2007 & 83 & 48 & 57.8 & 121.7 \\
\hline 2017 & 77 & 59 & 76.6 & 115.2 \\
\hline
\end{tabular}

Source: 1972 and 1993: Chamber of Agriculture, data taken from the Provincial Historical Archive, 2007 and 2017: District Agricultural Office of San Román (Regional Government of La Rioja). Compilation by the authors.

Figure 7 shows the evolution of professional livestock farms since 1972. At that time, there were 125 livestock farms, of which only 2 remained in 2017: 91 were lost from 19721993, 20 more from 1993-2007 and 12 more from 2007-2017. In addition, between 1972 and 1993, 53 new livestock farms were created, of which 14 survived in 2017. Between 1993 and 2007, 15 new farms were created, all of which are still operating. Lastly, between 2007 and 2017, another 28 livestock farms were created. Therefore, there are 59 livestock farms at present. Thus, Figure 7 reflects great dynamism in the livestock farms in the Leza valley, and recently a significant trend towards creating new ones.

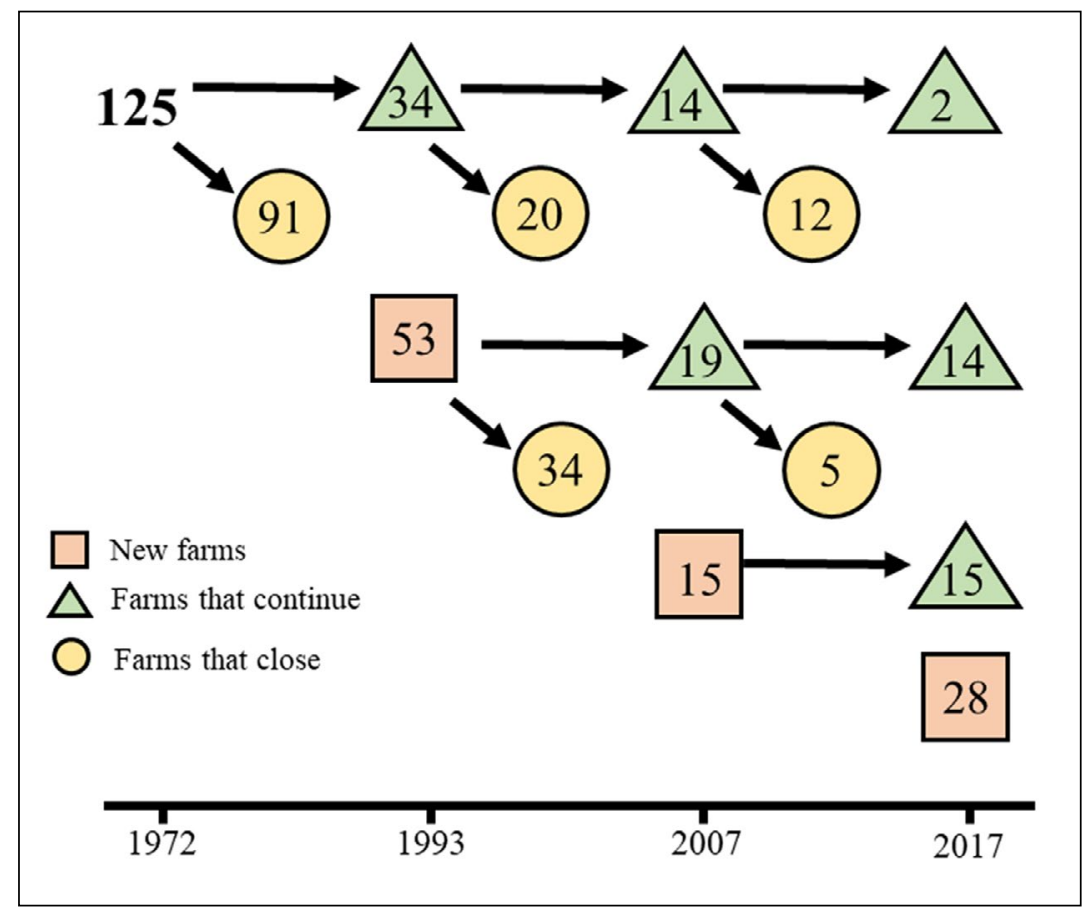

Figure 7. Origin and evolution (1972-2017) of the number of professional farms in the Leza Valley. 


\subsection{Livestock farms in 2017}

Out of 59 farms in the Leza valley in 2017, 34 belong to farmers born in the valley and so correspond to group $1 ; 12$ to group 2 (owners with ancestors in the Leza valley); and 13 to group 3 (owners with no previous links to the study area). These 28 "outsider" farms have been established over the last two decades.

Figure 8 shows that there are no significant differences among the three groups in the size of the farms $(\mathrm{p}=0.441)$. However, more variability is observed in the group 1 , and less in the group 2. Group 3 shows the highest average value $(126 \mathrm{LU})$, followed by group 1 (120.6 LU) and group 2 (87.7 LU). Nevertheless, the median value is slightly higher in group $1(111 \mathrm{LU})$ than in group $3(102 \mathrm{LU})$, whereas group 2 records the lowest median value $(68.5 \mathrm{LU})$.

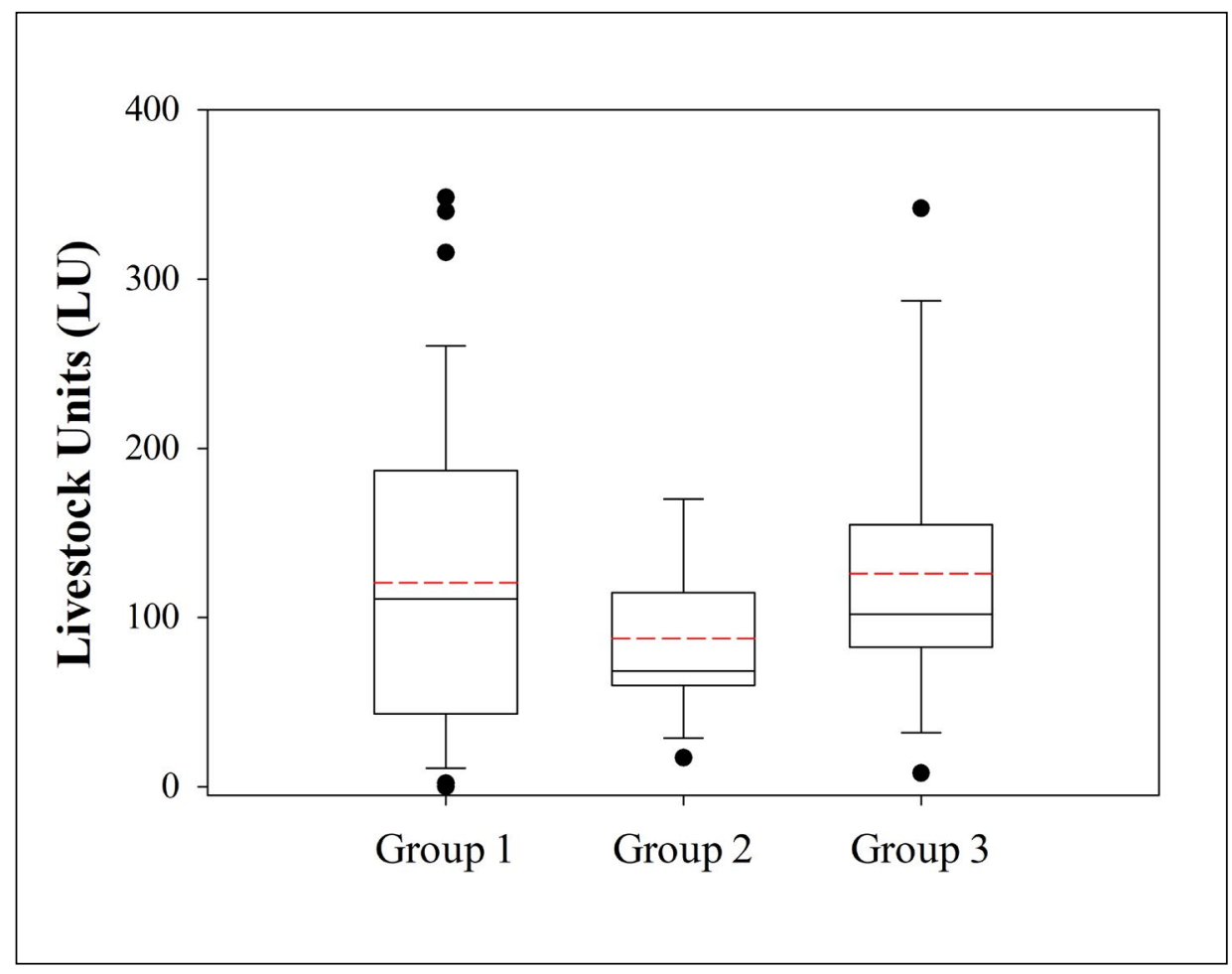

Figure 8. Livestock Units $(L U)$ related to the origin of farmers: Group 1. Owners from the study area; Group 2 owners related to families in the study area; Groups 3: owners with no previous ties to the Leza valley.

Figure 9 points out that the owners in group 1 are the oldest, with an average of 56.6 years old and a median of 58 , with over $75 \%$ of farm owners being over 50 years old. A comparison of the ages of owners in the three groups shows significant differences between group 1 and the other two groups $(\mathrm{p}<0.01)$. Group 2 consists of the youngest farmers, with an average 
age of 38.7 and median value of 35 years old. This group presents the highest variability (owners between 25 and 53 years old). Group 3 lies in the middle, with the farmers' average age at 45 years old, and the median at 42 (extreme values are 62 and 31 years old).

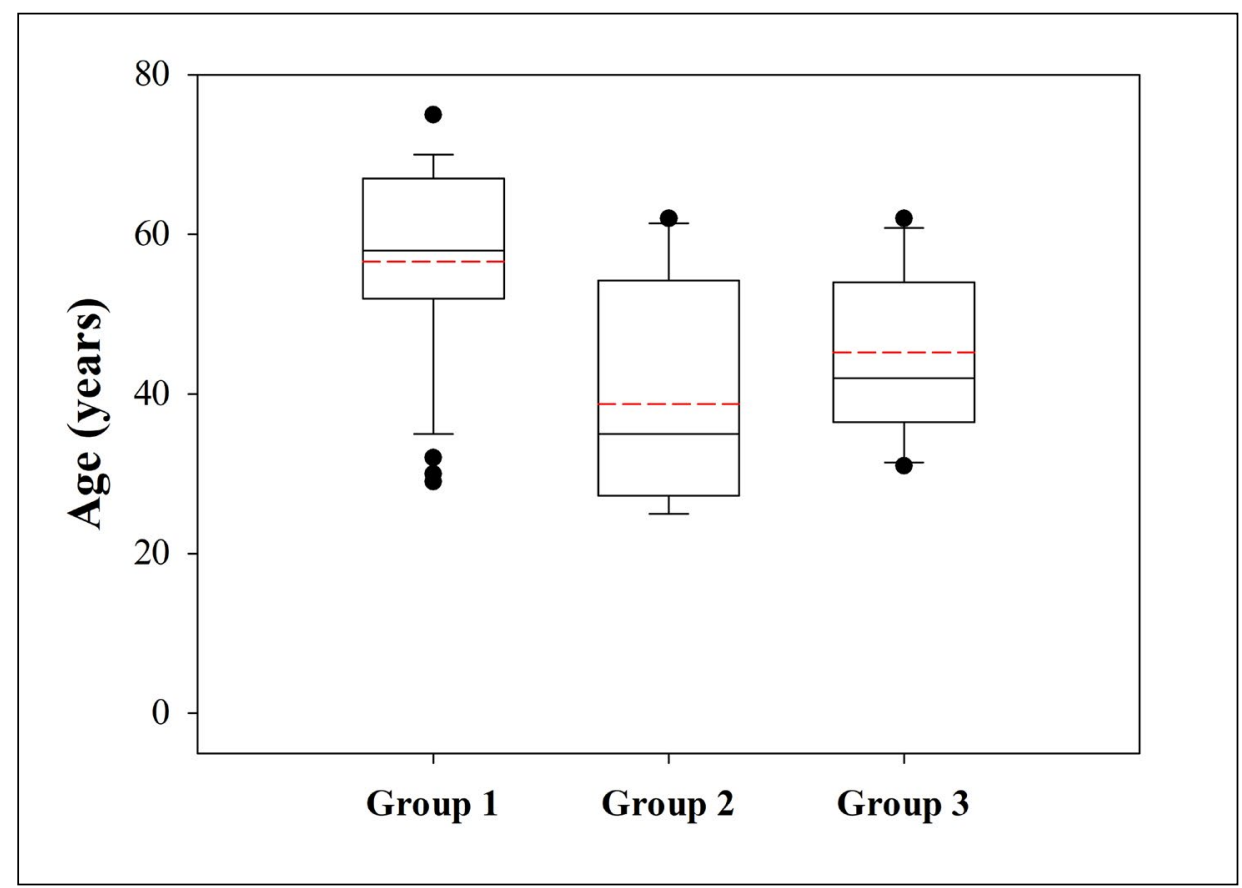

Figure 9. Age of farmers according to the origin of the exploitation. Group 1. Owners in the study area; Group 2 owners related to families in the study area; Groups 3: owners with no previous ties to the Leza valley.

\section{Discussion and conclusions}

From the beginning of the $20^{\text {th }}$ century, the Mediterranean mountain areas in Europe have undergone substantial abandonment of its traditional activities (MacDonald et al., 2000; Sancho-Reinoso, 2013), together with widespread growth in shrubland over the landscape (Tasser et al., 2007; Tzanopoulos et al., 2007; García-Ruiz and Lana-Renault, 2011; Alados et al., 2019). In the Spanish mountains, abandonment was particularly drastic in the decades between 1950 and 1970. Thus, cultivation ceased on most of the slopes (terraces, steep fields) and mountain agriculture concentrated on the valley floors, while the number of livestock farms decreased rapidly. This evolution was the consequence of strong limitations (topographical, climatic, lack of infrastructure, highly degraded landscape due to intense, historical human pressure, etc.) and the resulting depopulation faced by these mountains to integrate into a dynamic economy (GarcíaRuiz and Lasanta-Martínez, 1990; Lasanta et al., 2005; Shengfa and Xiubin, 2017). Currently, only very extensive systems requiring little manpower, such as extensive 
livestock farming, can be economically viable, provided that the farms reach a critical size and have abundant, cheap pasture. On the other hand, extensive livestock farming can generally contribute to landscape and soil conservation, which is also a guarantee of sustainability and biodiversity (Peco et al., 2006; Bernués et al., 2014).

This article has shown the experiences of the Leza valley, in which the regional Government of La Rioja has tried to promote extensive livestock farming through shrub clearing in selected areas. Between 1986 and 2016, 5390 ha were cleared, almost 30\% of the surface area hitherto covered by shrub. Most of the clearance occurred on abandoned fields, where the process of secondary succession led to the dominance of G. scorpius shrub on limestone substrate, and C. laurifolius on siliceous substrate (Arnáez et al., 2011). Removing shrub extends pastures with high quality species for livestock at a relatively low cost. This study has demonstrated that in areas of $G$. scorpius these are multiplied by 2.2 , from $4566 \mathrm{Mj} \mathrm{ha}^{-1}$ to $10,167.3 \mathrm{Mj} \mathrm{ha}^{-1}$, and in areas of $C$. laurifolius by 3.1 (from $2435.2 \mathrm{Mj} \mathrm{ha}^{-1}$ to $7628.6 \mathrm{Mj} \mathrm{ha}^{-1}$ ). This is explained by the presence of several plants with high grazing value under the shrub (Reiné et al., 2014). Most of the pasture is produced in spring and autumn, while it decreases in summer, due to higher evapotranspiration and because some plants do not recover after the spring grazing; it also decreases in winter, due to the plant cycle halting. Even so, shrub clearance encourages the movement of livestock and helps to reduce the lack of pasture, especially in the most critical seasons (winter and summer), since the cleared areas are accessible throughout the year, as it also occurs in the Spanish Pyrenees (Lasanta et al., 2006). It is noteworthy that the seasonal imbalance in the availability of pasture is one of the most limiting factors in implementing extensive livestock farming in the Mediterranean mountains (Cunningham, 1982; Puidefábregas and Fillat, 1986).

An important issue is that clearing leads to a greater increase in pasture than that which can be deduced from the analyses performed (see Table 3). The reason is that fields completely colonised with shrubs cannot be grazed, even though herbaceous plants good for grazing grow under the shrub. Therefore, clearing means that the old abandoned fields can feed $0.45 \mathrm{LU}$ in the case of GS and $0.33 \mathrm{LU}$ in the case of CL. It must also highlighted that the cleared areas are an attraction for livestock, as when they move towards them, they graze in nearby areas that would not be visited otherwise (Valdelvira and Balcells, 1986; Lécrivain and Beylier, 2004).

The best pasture resources have enabled an increase in livestock numbers, going from 1833.9 LU in 1972 to $7207.8 \mathrm{LU}$ in 2017, which means that they have multiplied by 3.9 in 45 years. The CAP has helped a great deal with this increase (García-Martínez et al., 2011), also the clearance policy of the regional Government of La Rioja, since the Leza valley has seen a much higher increase in livestock census that other mountain regions in Spain (García-Martínez et al., 2009). In that sense, in the Aragonese Pyrenean valleys, with higher livestock resources than those in the study area (meadows and subalpine and alpine pastures), the livestock census decreased (10.3\%) between 1972 and 2009, from 27.993 LU to 25.103 LU. On the other hand, the number of livestock farms has undergone a sharp decrease since 1972, because optimizing profits from extensive livestock requires a critical minimum dimension before receiving a return 
(Veyssier et al., 2005; Lasanta and Laguna Marín-Yaseli, 2007). In this respect, the average size of the farms is much larger in the study area $(115.2 \mathrm{LU})$ than in Spain as a whole (53 LU), whereas the average age of the owners (MARM, 2010) is lower in the study area. The availability of new pastures and grazing facilities arising from shrub clearance has encouraged the creation of new farms $(41.7 \%)$, mainly managed by people under 40 years old. This promotes continuing livestock farming in the medium term, provided that the public policies supporting livestock remain (Dobbs and Pretty, 2004; Foran, 2007; García-Martínez et al., 2009; Puig et al., 2011).

Extensive livestock needs (i) abundant natural pastures that are relatively accessible, (ii) pasture systems based on a knowledge of the heterogeneity of the region and the seasonal variability in productivity, and (iii) young, entrepreneurial workers willing to accept the drawbacks involved in farming in marginal mountain areas. Consequently, clearance policies for former crop fields are a decisive basis in facilitating livestock grazing, attracting new entrepreneurs and lowering production costs. It must not be forgotten that in marginal regions such as the Mediterranean mountains, the expansion of shrubland during the $20^{\text {th }}$ century was a significant factor when explaining the lack of enthusiasm in many farmers, especially the younger ones. In fact, they were the ones who cited the expansion of shrub as one of the most serious problems in developing livestock (Fernández-Giménez and Fillat, 2012; Lasanta et al., 2016).

\section{Acknowledgements}

This research was supported by the ESPAS project (CGL2015-65569-R, funded by the MINECO-FEDER) and ECOHIPRO (1560/2015), funded by the Natural ParksMinistry of Agriculture and Environment. The "Geomorphology and Global Change" and the "Climate, water, global change and natural systems" research groups were financed by the Aragón Government and the European Social Fund (ESF-FSE). Estela Nadal-Romero was the recipient of a "Ramón y Cajal" postdoctoral contract (RYC2013-14371, Spanish Ministry of Economy and Competitiveness).

\section{References}

Alados, C.L., Sáiz, H., Nuche, P., Gartzía, M., De Frutos, Á., Pueyo, Y. 2019. Clearing vs. burning for restoring grasslands after shrub encroachment. Cuadernos de Investigación Geográfica 45(2), 437-464. http://doi.org/10.18172/cig.3589.

Amella, A., Ferrer, C. 1979. Utilización de un método fitosociológico en la determinación del valor nutritivo de los pastos. Trabajos del I.E.P.G.E, 37, CSIC- Universidad de Zaragoza. 10 pp.

Arnáez, J., Ortigosa, L., Oserín, M., Lasanta, T. 2009. Evolución de la cubierta vegetal en Cameros entre 1956 y 2001. In: T. Lasanta, J. Arnáaez (Eds.), Gestión, usos del suelo y paisaje en Cameros: Sistema Ibérico, La Rioja. Universidad de La Rioja e Instituto de Estudios Riojanos, Logroño, pp. 127-144.

Arnaéz, J., Lasanta, T., Errea, M.P., Ortigosa, L. 2011. Land abandonment, landscape evolution, and soil erosion in a Spanish Mediterranean mountain region. The case of Camero Viejo. Land Degradation \& Development 22, 537-550. https://doi.org/10.1002/ldr.1032.

Ascaso, J. 1990. Estudio fitocenológico y valoración de recursos pastorales de las zonas forestadas y arbustivas del Prepirineo aragonés. Institución Fernando el Católico, Zaragoza, 152 pp. 
Ascaso, J., Ferrer, C., Maestro, M. 1996. Valoración estacional y anual de los recursos pastables en el Maestrazgo de Castellón. Actas de la XXXVI Reunión Científica de la Sociedad Española para el Estudio de los Pastos, pp. 161-166.

Barrantes, O., Reiné, R., Ascaso, J., Mendoza, A., Broca, A., Ferrer, C. 2004. Pastos arbustivos y pastizales del tipo lasto-timo-aliagar de la depresión del Ebro en la provincia de Huesca. Tipificación, cartografía y valoración. Actas de la XLIV Reunión Científica de la Sociedad Española para el Estudio de los Pastos, pp. 625-630.

Bernués, A., Riedel, J.L., Asensio, M.A., Blanco, M., Sanz, A., Revilla, R., Casasús, I. 2005. An integrated approach to studying the role of grazing livestock systems in the conservation of rangelands in a protected natural park (Sierra de Guara, Spain). Livestock Production Science 96, 75-85. https://doi.org/10.1016/j.livprodsci.2005.05.023.

Bernués, A., Rodríguez-Ortega, T., Ripoll-Bosch, R., Alfnes, F. 2014. Socio-cultural and economic valuation of ecosystem services provided by Mediterranean mountain agroecosystems. PLoS ONE 9 (7), e102479. https://doi.org/10.1371/journal.pone.0102479.

Blondel, J. 2006. The "design" of Mediterranean landscapes: a millennial story of humans and ecological systems during the historic period. Human Ecology 34, 713-729. https://doi. org/10.1007/s10745-006-9030-4.

Collantes, F. 2004. El declive demográfico de la montaña Española (1850-2000): ¿un drama rural? Ministerio de Agricultura, Pesca y Alimentación, Madrid, 372 pp.

Conti, G., Fagarazzi, L. 2005. Forest expansion in mountain ecosystems: "environmentalist's dream" or societal nightmare? Planum 11, 1-20. http://www.planum.net/download/conti_fagarazzi_en-pdf.

Cooper, T., Baldock, D., Rayment, M., Kuhuionen, T., Terluin, I., Swales, V., Poux, X., Zakeossian, D., Farmer, M. 2006. An evaluation of the less favoured area measure in the 25 member states of the European Union. Institute for European Environmental Policy, London, 262 pp. Available at: https://ec.europa.eu/agriculture/evaluation/rural-development-reports/2006-lfa_en.

Cuadrat, J.M., Vicente-Serrano, S. 2008. Características espaciales del clima en La Rioja modelizadas a partir de Sistemas de Información Geográfica y técnicas de regresión espacial. Zubía. Monográfico 20, 119-142.

http://digital.csic.es/bitstream/10261/77673/1/SergioVicente_climaRioja2008.pdf.

Cunningham, J.M.M. 1982. Extensive grazing systems. In: I.E. Coop (Ed.), Sheep and goat production. Elsevier, Amsterdam, pp. 331-350.

Daget, P., Poissonet, J. 1979. Un procédé d'estimation de la valeur pastorale des paturages. Fourrages 49, 31-39.

Dax, T. 2005. The redefinition of Europe's Less Favoured Areas. Munich Personal RePEcArchive (MPRA), Paper $\mathrm{N}^{\circ}$ 711. November 2006. Available at: http://mpra.ub.unimuenchen.de.

DG Agriculture 2011. Rural development in the European Union. Statistical and economic information report, $257 \mathrm{pp}$.

Dobbs, T.L.,Pretty,J.N.2004. Agri-environmental stewardship schemes and "multifunctionality". Review of Agricultural Economics 26, 220-237. https://doi.org/10.1111/j.1467-9353.2004.00172.x.

Douglas, T.D., Kirkby, S.J., Critchley, R.W., Park, G.J. 1994. Agricultural terrace abandonment in the Alpujarra, Andalucia, Spain. Land Degradation and Rehabilitation 5, 281-291. https:// doi.org/10.1002/ldr.3400050405.

Ejarque, A., Miras, Y., Riera, S., Palet, J.M., Orengo, H.A. 2010. Testing micro-regional variability in the Holocene shaping of high mountain cultural landscapes: A palaeoenvironmental casestudy in the eastern Pyrenees. Journal of Archaeological Science 37, 1468-1479. https://doi. org/10.1016/j.jas.2010.01.007.

Errea, M.P., Lasanta, T., Arnáez, J., Ortigosa, L., Ruiz-Flaño, P., Oserín, M. 2009. Cambios en el paisaje de Cameros durante la segunda mitad del siglo XX. In: T. Lasanta, J. Arnáez (Eds.), 
Gestión, usos del suelo y paisaje en Cameros: Sistema Ibérico, La Rioja. Universidad de La Rioja e Instituto de Estudios Riojanos, Logroño, pp. 165-190.

Fernández-Giménez, M., Fillat Estaque, F. 2012. Pyrenean pastoralists’ ecological knowledge documentation and application to natural resource management and adaptation. Human Ecology 40, 287-300. https://doi.org/10.1007/s10745-012-9463-x.

Ferrer, C., Maestro, M., Hamrouni, S., Ocaña, M. 1993. Valoración de pastos del Alt Maestrat (Castellón). Zaragoza, 624 pp.

Fillat, F., García-González, R., Gómez, D., Reiné, R. (Eds.) 2008. Pastos del Pirineo. CSIC, Madrid, 319 pp.

Foran, B.D. 2007. Sifting the future from the past: a personal assessment of trends impacting the Australian rangelands. The Rangeland Journal 29, 3-11. https://doi.org/10.1071/RJ07019.

Frealand, W.J., Choquenot, D. 1990. Determinants of herbivore carrying capacity: plants, nutrients and Equus asinus, in Northern Australia. Ecology 71, 589-597. https://doi. org/10.2307/1940312.

García-González, R., Marinas, A. 2008. Bases ecológicas para la ordenación de territorios pastorales. In: F. Fillat, R. García-González, D. Gómez, R. Reiné (Eds.), Pastos del Pirineo, CSIC, Madrid, pp. 229-253.

García-Martínez, A., Olaizola, A., Bernués, A. 2011. Trajectories of evolution and drivers of change in European mountain cattle farming systems. Animal 3 (1) 152-165. https://doi. org/10.1017/S1751731108003297.

García-Martínez, A., Bernués, A., Olaizola, A. 2009. Simulation of mountain cattle farming systems changes under diverse agricultural policies and off-farm scenarios. Livestock Science 137, 73-86. https://doi.org/10.1016/j.livsci.2010.10.002.

García-Ruiz, J.M. 1976. Modos de vida y niveles de renta en el Prepirineo del Alto Aragón Occidental. Monografías del Instituto de Estudios Pirenaicos 106, Jaca, 272 pp. Available at: http://digital.csic.es/handle/10261/96875.

García-Ruiz, J.M., Lasanta-Martínez, T. 1989. La ganadería extensiva en áreas montañosas marginales: algunos problemas teóricos y prácticos. Anales del Instituto de Estudios Agropecuarios 11, 77-93.

García-Ruiz, J.M., Lasanta-Martínez, T. 1990. Land use changes in the Spanish Pyrenees. Mountain Research and Development 10 (3), 267-279. https://doi.org/10.2307/3673606.

García-Ruiz, J.M., Lasanta-Martínez, T. 1993. Land-use conflicts as a result of land-use change in the Central Spanish Pyrenees: A review. Mountain Research and Development 13 (3), 295 304. https://doi.org/10.2307/3673658.

García-Ruiz, J.M., Lana-Renault, N. 2011. Hydrological and erosive consequences of farmland abandonment in Europe, with special reference to the Mediterranean región - A review. Agriculture, Ecosystems and Environment 140, 317-338. https://doi.org/10.1016/j. agee.2011.01.003.

García-Ruiz, J.M., Lasanta, T. 2018. El Pirineo aragonés como paisaje cultural. Pirineos 137, e038. https://doi.org/10.3989/pirineos.2018.173005.

García-Ruiz, J.M. 1988. La evolución de la agricultura de montaña y sus efectos sobre la dinámica del paisaje. Revista de Estudios Agrosociales 147, 7-37. http://www.mapama.gob.es/ ministerio/pags/biblioteca/revistas/pdf_reas/r146_01.pdf.

García-Ruiz, J.M., Arnáez, J., Lasanta, T. 2017. Complejidad y diversidad en el paisaje de la montaña riojana: Una perspectiva general sobre su proceso de construcción y transformación. Berceo 173, 141-164.

García-Ruiz, J.M., López-Moreno, J.I., Vicente-Serrano, S., Lasanta, T., Beguería, S. 2011. Mediterranean water resources in a Global Change scenario. Earth Science Reviews 105 (34), 121-139. https://doi.org/10.1016/j.earscirev.2011.01.006. 
García-Ruiz, J.M., Sanjuán, Y., Gil-Romera, G., González-Sampériz, P., Arnáez, J., Coba Pérez, P., Gómez-Villar, A., Álvarez-Martínez, J., Lana-Renault, N., Pérez-Cardiel, E., López de Calle, C. 2016. Mid and Late Holocene forest fires and deforestation in the Subalpine belt of the Iberian Range, Northern Spain. Journal of Mountain Science 13 (19), 1760-1772. https:// doi.org/10.1007/s11629-015-3763-8.

Gartzia, M., Alados, C.L., Pérez-Cabello, F. 2014. Assessment of the effects of biophysical and anthropogenic factors on woody plant encroachment in dense and sparse mountain grasslands based on remote sensing data. Progress in Physical Geography 38, 201-217. https://doi. org/10.1177/0309133314524429.

Gellrich, H., Bauer, P., Koch, B., Zimmermann, N.E. 2007. Agricultural land abandonment and natural forest re-growth in the Swiss mountains: A spatial explicit economic analysis. Agriculture, Ecosystems and Environment 118, 93-108. https://doi.org/10.1016/j. agee.2006.05.001.

Gil-García, M.J., Tomás Las Heras, R., Núñez Olivera, E., Martínez Abaigar, J. 1996. Acción humana sobre el medio natural en la Sierra de Cameros a partir del análisis polínico. Zubía. Monográfico 8, 29-41. https://dialnet.unirioja.es/servlet/articulo?codigo=110342.

Gil-García, M.J., Dorado Valiño, M., Valdeolmillos Rodríguez, A., Ruiz Zapata, M.B. 2002. Late glacial and Holocene palaeoclimatic record from Sierra Cebollera (northern Iberian Range, Spain). Quaternary International 93-94, 13-18. https://doi.org/10.1016/S10406182(02)00003-4.

Gómez Urdáñez, J.L. 1986. Subsistencia y descapitalización en el Camero Viejo al final del Antiguo Régimen. Cuadernos de Investigación Histórica. Brocar 12, 103-140.

Gómez Urdáñez, J.L., Moreno Fernández, J.R. 1997. El problema agrario en las sierras de La Rioja: de la propiedad a la subsistencia (siglos XVIII-XIX). Agricultura y Sociedad 82, 79113.

Kaplan, J.O., Krumhardt, K.M., Zimmermann, N. 2009. The prehistoric and preindustrial deforestation of Europe. Quaternary Science Review 28, 3016-3034. https://doi.org/10.1016/j. quascirev.2009.09.028.

Keenleyside, C., Tucker, G.M. 2010. Farmland abandonment in the EU: an assessment of trends and prospects. Report prepared for WWF. Institute for European Environmental Policy, London, $93 \mathrm{pp}$.

Kuyvenhoven, A., Pender, J. 2004. Editorial: Development strategies for less-favoured areas. Food Policy 29, 295-302. https://doi.org/10.1016/j.foodpol.2004.08.001.

Laguna Marín-Yaseli, M., Lasanta-Martínez, T. 2007. Assessment of public policies related to rural development in the Aragonese Pyrenees. Boletín de la Asociación de Geógrafos Españoles 43, 365-368. http://age.ieg.csic.es/boletin/43/02_LAGUNA.pdf.

Lasanta, T. 1990. Tendances actuelles de l'organization spatiale des montagnes espagnoles. Annales de Géographie 551, 51-71. https://doi.org/10.3406/geo.1990.20944.

Lasanta, T. 2002. Los sistemas de gestión en el Pirineo central español durante el siglo XX: del aprovechamiento global de los recursos a la descoordinación espacial en los usos del suelo. Ager 2, 173-195.

Lasanta, T. 2009. La ganadería en Cameros: entra la adaptación a los recursos y la dependencia del exterior. In: T. Lasanta, J. Arnáez (Eds.), Gestión, usos del suelo y paisaje en Cameros: Sistema Ibérico, La Rioja. Universidad de La Rioja e Instituto de Estudios Riojanos, Logroño, pp. 191-222.

Lasanta, T. 2014. El paisaje de campos abandonados en Cameros Viejo (Sistema Ibérico, La Rioja). Instituto de Estudios Riojanos. Colección Ciencias de la Tierra 32, Logroño, 305 pp.

Lasanta, T., Errea, M.P. 2001. Despoblación y marginación en la Sierra Riojana. Instituto de Estudios Riojanos, Logroño, 181 pp. 
Lasanta, T., Laguna Marín-Yaseli, M. 2007. Effects of European Common Agricultural and Regional Policy on the socioeconomic development of the Central Pyrenees (Spain). Mountain Research and Development 27 (2), 130-137. https://doi.org/10.1659/mrd.0840.

Lasanta, T., Vicente-Serrano, S., Cuadrat, J.M. 2005. Mountain Mediterranean landscape evolution caused by abandonment of traditional primary activities: a study of the Spanish Central Pyrenees. Applied Geography 25, 47-65. https://doi.org/10.1016/j.apgeog.2004.11.001

Lasanta, T., González-Hidalgo, J.C., Vicente-Serrano, S.M., Sferi, E. 2006. Using landscape ecology to evaluate an alternative management scenario in abandoned Mediterranean mountainous areas. Landscape and Urban Planning 78, 101-114. https://doi.org/10.1016/j.landurbplan.2005.06.003.

Lasanta, T., Errea, M.P., Bouzebboudja, M.R., Medrano, L.M. 2013. Pastoreo y desbroce de matorrales en Cameros Viejo. Instituto de Estudios Riojanos. Colección Ciencias de la Tierra 32, Logroño, $186 \mathrm{pp}$.

Lasanta, T., Nadal-Romero, E. Arnáez, J. 2015. Managing abandoned farmland to control the impact of re-vegetation on the environment. The state of art in Europe. Environmental Science \& Policy 52, 99-109. https://doi.org/10.1016/j.envsci.2015.05.012.

Lasanta, T., Nadal-Romero, E., Errea, M.P., Arnáez, J. 2016. The effects of landscape conservation measures in changing landscape patterns: a case study in Mediterranean mountain. Land Degradation \& Development 27, 373-386. https://doi.org/10.1002/ldr.2359.

Lécrivain, E., Beylier, B. 2004. Technique de réouverture d'une colline embroussaillée adaptée au comportement des troupeaux. Optinons Méditerranéennes 62, 233-238.

López de Calle, C., Pérez Arrondo, C. 1995. Fechas de radiocarbono y fases de ocupación en los sepulcros megalíticos de Cameros (La Rioja). Istúriz: Prehistoria-Arqueología 6, 343-360.

López de Calle, C., Tudanca, J.M. 2014. Contemplando Cameros desde la Arqueología: actitudes y planteamientos metodológicos en la interpretación del paisaje. Berceo 167, 121-176. https:// dialnet.unirioja.es/servlet/articulo?codigo $=4886724$.

López de Calle, C., Iriarte, M.J., Zapata, L. 2001. Análisis paleoambientales en el dolmen de Collado del Mallo (Trevijano, La Rioja). Viabilidad y trabas de la paleoecología vegetal en estructuras dolménicas. Zubía. Monográfico 13, 65-96.

MacDonald, D., Crabtree, J.R., Wiesinger, G., Dax, T., Stamon, N., Fleury, P., Gutiérrez-Lazpita, J., Gibon, A. 2000. Agricultural abandonment in mountain areas of Europe: environmental consequences and policy response. Journal of Environmental Management 59, 47-69. https:// doi.org/10.1006/jema.1999.0335.

Marcos, I., García-Morrás, J.A., Medrano, L.M., Torrano, L. 2004. Evaluación de los recursos pascícolas naturales en La Rioja. Actas de la XLIV Reunión Científica de la Sociedad Española para el Estudio de los Pastos, 585-590 pp.

Marey-Pérez, M.F., Rodríguez-Vicente, V. 2009. Forest transition in Northern Spain: local responses on large-scale programmes of field-afforestation. Land Use Policy 26 (1), 139-156. https://doi.org/10.1016/j.landusepol.2008.02.004.

MARM, 2010. Estudio del sector español de vacas nodrizas (Datos: SITRAN). Subdirección General de Productos Ganaderos, Ministerio de Medio Ambiente, Rural y Marino. Informe Técnico, 17 pp. Available at: http://www.marm.es.

Martín Bellido, M., Espejo Díaz, M., Plaza Gonzalo, J., López Carrión, T. 1986. Metodología para la determinación de la carga ganadera de pastos extensivos. Ministerio de Agricultura, Madrid, $37 \mathrm{pp}$.

MEA. Millennium Ecosystems Assessments. 2003. Ecosystems and Human Well-being: A Framework for Assessment. Island Press, Washington, DC, USA.

Mottet, A., Ladet, S., Coque, N., Gibon, A. 2006. Agricultural land-use change and its drivers in mountain landscapes: A case study in the Pyrenees. Agriculture, Ecosystems and Environment 114, 296-310. https://doi.org/10.1016/j.agee.2005.11.017. 
Navarro, L.M., Pereira, H.M. 2012. Rewilding abandoned landscapes in Europe. Ecosystems 15, 900-912. https://doi.org/10.1007/s10021-012-9558-7.

Olarieta, J.R., Rodríguez-Valle, F.L., Tello, E. 2008. Preserving and destroying soils, transforming landscapes: soils and land-use changes in the Vallès County (Catalunya, Spain) 1853-2004. Land Use Policy 25, 474-484. https://doi.org/10.1016/j.landusepol.2007.10.005.

Ortigosa, L. 1991. Las repoblaciones forestales en La Rioja: resultados y efectos geomorfológicos. Geoforma Ediciones, Logroño, 149 pp.

Ortigosa, L.M., García-Ruiz, J.M., Gil, E. 1990. Land reclamation by reforestation in the Central Pyrenees. Mountain Research and Development 10 (3), 282-288. https://doi. org/10.2307/3673607.

Peco, B., Sánchez, A., Azcárate, F. 2006. Abandonment in grazing systems: consequences for vegetation and soil. Agriculture, Ecosystems and Environment 113, 1-4. https://doi. org/10.1016/j.agee.2005.09.017.

Poyatos, R., Latron, J., Llorens, P. 2003. Land use and land cover change after agricultural abandonment -the case of a Mediterranean mountain area (Catalan Pre-Pyrenees). Mountain Research and Development 23: 362-368. https://doi.org/10.1659/02764741(2003)023[0362:LUALCC]2.0.CO;2.

Puig, C.J., Greiner, R., Huchery, C., Perkins, I., Bowen, L., Collier, N., Garmett, S.T. 2011. Beyond cattle: potential futures of the pastoral industry in the Northern Territory. The Rangeland Journal 33, 181-194. https://doi.org/10.1071/RJ10043.

Puigdefábregas, J., Fillat, F. 1986. Ecological adaptation of traditional land-uses in the Spanish Pyrenees.Mountain Research and Development 6 (1),63-73.https://doi.org/10.2307/3673341.

Reiné, R., Barrantes, O., Broca, A., Gonzalo, S., Ascaso, J., Ferrer, C. 2005. Pastos arbustivos de aliagar y de romeral en la Cordillera Ibérica de Aragón. Tipificación, Cartografía y Valoración. Actas de la XLV Reunión Científica de la Sociedad Española para el Estudio de Pastos, pp. 751-761.

Reiné, R., Barrantes, O., Chocarro, C., Juárez, A., Broca, A., Ferrer, C. 2014. Pyrenean meadows in Natura 2000 network: Grass production and policy biodiversity conservation. Spanish Journal of Agricultural Research 12 (1), 61-77. https://doi.org/10.5424/sjar/2014121-4617.

Rescia, A.J., Pons, A., Lomba, I., Esteban, C., Dover, J.W. 2008. Reformulating the social-ecological systems in a cultural rural mountain landscape in the Picos de Europe región (Nothern Spain). Landscape and Urban Planning 88, 23-33. https://doi.org/10.1016/j.landurbplan.2008.08.001.

Rey-Benayas, J.M., Martins, A., Nicolau, J.M., Schulz, J.J. 2007. Abandonment of agricultural land: an overview of drivers and consequences. CAB Rev 2, 1-14. https://doi.org/10.1079/ PAVSNNR20072057.

Ruben, R., Pender, J. 2004. Rural diversity and heterogeneity in less-favoured areas: the quest for policy targeting. Food Policy 29, 303-320. https://doi.org/10.1016/j.foodpol.2004.07.004.

Sancho-Reinoso, A. 2013. Land abandonment and the dynamics of agricultural landscapes in Mediterranean mountain environments: The case of Ribagorça (Spanish Pyrenees). Erdkunde 67(4), 289-308. https://doi.org/10.3112/erdkunde.2013.04.01.

San Román Sanz, A., Fernández, C., Mouillot, F., Ferrat, L., Istria, D., Pasqualini, V. 2013. Longterm forest dynamics and land-use abandonment in the Mediterranean mountains, Corsica, France. Ecology and Society 18 (2), 38. http://dx.doi.org/10.5751/ES-05556-180238.

Sanjuán, Y., Arnáez, J., Beguería, S., Lana-Renault, N., Lasanta, T., Gómez-Villar, A., ÁlvarezMartínez, J., Coba-Pérez, P., García-Ruiz, J.M. 2018. Woody plant encroachment following grazing abandonment in the subalpine belt: a case study in northern Spain. Regional Environmental Change 18, 1103-1115. https://doi.org/10.1007/s10113-017-1245-y.

Shengfa, L., Xiubin, L. 2017. Global understanding of farming abandonment: A review and prospects. Journal of Geographical Science 27 (9), 1123-1150. https://doi.org/10.1007/s11442-017-1426-0. 
Sitzia, T., Semenzato, P., Trentanovi, G. 2010. Natural reforestation is changing spatial patterns of rural mountain and hill landscapes: A global overview. Forest Ecology and Management 259, 1354-1362. https://doi.org/10.1016/j.foreco.2010.01.048.

Stoate, C., Báldi, A., Beja, P., Boatman, N.D., Herzon, I., Van Doorn, A., De Snoo G.R., Rakosy, I., Ramwell, C. 2009. Ecological impacts of early $21^{\text {st }}$ century agricultural change in EuropeA review. Journal of Environmental Management 91, 22-46. https://doi.org/10.1016/j. jenvman.2009.07.005.

Svenning, J.C. 2002. A review of natural vegetation openness in North-western Europe. Biological Conservation 104 (2), 133-148. https://doi.org/10.1016/S0006-3207(01)00162-8.

Tasser, E., Walde, J., Tappeiner, U., Teutsch, A., Noggler, W. 2007. Land-use changes and natural reforestation in the Eastern Central Alps. Agriculture, Ecosystems and Environment 118, 115-129. https://doi.org/10.1016/j.agee.2006.05.004.

Tzanopoulos, J., Mitchley, J., Pantis, J.D. 2007. Vegetation dynamics in abandoned crop fields on a Mediterranean island: development of succession model and estimation of disturbance thresholds. Agriculture, Ecosystems and Environment 83, 83-94. https://doi.org/10.1016/j. agee.2006.10.011.

Valdelvira, A., Balcells, E. 1986. La pardina de Esporret como unidad empresarial de las Sierras meridionales. Pirineos 128, 79-118.

Veysset,P., Bebin, D., Lherm, M. 2005. Adaptation to Agenda 2000 (CAP reform) and optimisation of the farming system of French suckler cattle farms in the Charolais area: a model-based study. Agricultural Systems 83, 179-202. https://doi.org/10.1016/j.agsy.2004.03.006.

Viviroli, D., Weingartner, R., Messerli, B. 2003. Assessing the hydrological significance of the Worlds's mountains. Mountain Research and Development 23, 32-40. https://doi. org/10.1659/0276-4741(2003)023[0032:ATHSOT]2.0.CO;2. 